\title{
Bird distribution dynamics - Indigenous francolins in South Africa, Lesotho, and Swaziland
}

Author(s):

Lerm RE, Jansen R, and Underhill

LG
Journal editor:

Pete Laver

Manuscript editor:

Pete Laver

Received: June 14, 2018; Accepted: March 22, 2019; Published: March 25, 2019

\section{Citation: Lerm RE, Jansen R, and Underhill LG. 2019. Bird distribution dynamics - Indigenous francolins in South Africa, Lesotho, and Swaziland. Biodiversity Observations 10.5:1-31}

Journal: https://journals.uct.ac.za/index.php/BO/

Manuscript: https://journals.uct.ac.za/index.php/BO/article/view/599

PDF: https://journals.uct.ac.za/index.php/BO/article/view/599/592

HTML: http:/ / thebdi.org/blog/2019/03/22/francolin-distributions
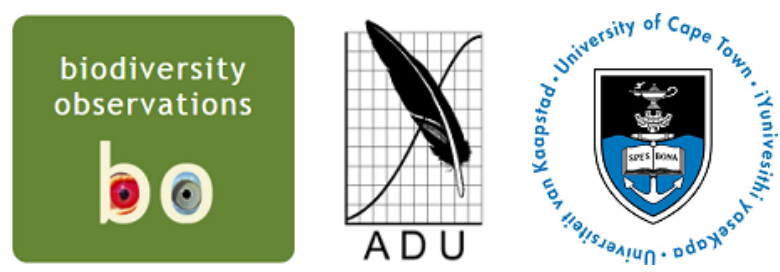

Biodiversity Observations is an open access electronic journal published by the Animal Demography Unit at the University of Cape Town, available at https://journals.uct.ac.za/index.php/BO/

The scope of Biodiversity Observations includes papers describing observations about biodiversity in general, including animals, plants, algae and fungi. This includes observations of behaviour, breeding and flowering patterns, distributions and range extensions, foraging, food, movement, measurements, habitat and colouration/plumage variations. Biotic interactions such as pollination, fruit dispersal, herbivory and predation fall within the scope, as well as the use of indigenous and exotic species by humans. Observations of naturalised plants and animals will also be considered. Biodiversity Observations will also publish a variety of other interesting or relevant biodiversity material: reports of projects and conferences, annotated checklists for a site or region, specialist bibliographies, book reviews and any other appropriate material. Further details and guidelines to authors are on the journal website (https://journals.uct.ac.za/index.php/BO/). 


\title{
Bird distribution dynamics - Indigenous francolins in South Africa, Lesotho, and Swaziland
}

\author{
Rion E Lerm South African Environmental Observation Network, Phalaborwa, South Africa \\ Raymond Jansen Department of Environmental, Water and Earth Sciences, Tshwane University of Tech- \\ nology, Pretoria, South Africa
}

Les G Underhill Animal Demography Unit, Department of Biological Sciences, University of Cape Town, Rondebosch, South Africa

\section{Introduction}

The objective of this series of papers on bird distribution dynamics in Biodiversity Observations is to report on the ranges of bird species as revealed by the Second Southern African Bird Atlas Project (SABAP2, 2007 onwards) and to describe how their ranges have changed since the first bird atlas (SABAP1, mainly 1987-1991), about two decades apart.

This series of papers is also made feasible by the development of two new standards for the presentation of maps, firstly pentad-scale distribution maps derived from SABAP2 data, and secondly range-change maps showing how distributions have changed between SABAP1 and SABAP2 (Underhill \& Brooks 2016a, b). Because the papers in this series use these two new interpretations in the form of maps, the rules for interpretation are not provided in detail in each of the "bird distribution dynamics" paper series.

Here, we deal with some of the economically important species of cursorial gamebirds belonging to the order Galliformes (family Phasianidae), that occur in South Africa, Lesotho and Swaziland. For each species, four items of information are presented: the SABAP1 distribution map using quarter-degree grid cells, the SABAP2 distribution map, using pentads (five-minute grid cells; there are nine pentads per quarter-degree grid cell), the range-change map, showing estimated changes in relative abundance between SABAP1 and SABAP2, and a table which provides counts of the numbers of grid cells shaded each of the six colours in the range change map.

The six terrestrial gamebird species dealt with are divided under the genera: Peliperdix, Dendroperdix and Scleroptila. Unfortunately, most of these francolin species are cryptic and inconspicuous making field identification difficult however, since citizen scientists were the source of observers across both SABAPs, possible errors in reporting rates should be similar for both projects. We expect that at least the more important range-change maps depict accurate changes in bird distribution.

Additionally, and compared to previous papers in this series, the national land cover dataset (GeoTerraImage 2015), and biomes and bioregions according to Mucina and Rutherford (2006)

Biodiversity Observations is an open access electronic journal published by the Animal Demography Unit at the University of Cape Town, available at https://journals.uct.ac.za/index.php/BO/. A permanent link for an online version of this manuscript can be found at https://journals.uct.ac.za/index.php/BO/article/view/599, which includes the PDF: https://journals.uct.ac.za/index.php/BO/article/view/599/592. An HTML version can be found at http:/ / thebdi.org/blog/2019/03/22/francolin-distributions.

Journal editor: Pete Laver; Manuscript editor: Pete Laver; Corresponding author: rion@saeon.ac.za

Received: June 14, 2018; Accepted: March 22, 2019; Published: March 25, 2019

Recommended citation: Lerm RE, Jansen R, and Underhill LG. 2019. Bird distribution dynamics - Indigenous francolins in South Africa, Lesotho, and Swaziland. Biodiversity Observations 10.5:1-31

Manuscript subject: Avian distribution 
were underlying the range-change data to get some insights into which habitats might have influenced decreases and increases in species distributions.

\section{Introduction to the francolins}

Of the global extant francolin species $(n=14)$ belonging to the aforementioned genera, $21 \%(n=3)$ are in a global threat category: in this case all 'Near-threatened'. These Red-listed species belong to the Scleroptila genus and occur mostly in East Africa with sub-populations of one species remaining in Cameroon \{West Africa; BirdLife International (2018) IUCN Red List for birds. Downloaded from http:/ / www.birdlife.org on 14/02/2018\}.

In South Africa, pressure from wing shooters and livestock grazing around the earlier 1900s caused certain populations of gamebirds in South Africa to survive where others did not, resulting in fragmented populations or local extinctions. However, species such as grey-winged francolin Scleroptila africanus, increased in the Eastern Cape grassland following the inland settlement by European farmers. Past introductions of foreign gamebirds have fortunately and, for some reason (possibly due to blood parasites) been unsuccessful (Little and Crowe 2011).

The assessment of changes in abundance for the species discussed here (from SABAP1 to SABAP2) is not further complicated by migratory habits, due to their mostly resident statuses. The species accounts are ordered in ascending Roberts number order as published by Hockey et al. (2005).

\section{Coqui francolin Peliperdix coqui}

The range-change map (Figure 4) of this highly localised gamebird raised concern due to very large and widespread decreases (57-60\% of grid cells where it was recorded) across most of its core distribution range that falls broadly within South Africa's Savanna Biome (Mucina \& Rutherford 2006). Since SABAP1, this species' distribution seemed to shift towards biomes containing habitats that are more diverse in vegetation structure and land-use compared to its favoured tall-grassed and open woodland habitats. Where this species historically avoided agricultural fields (Little 2005a), the GeoTerra Image (2015) land cover dataset of 2013-2014 showed Coqui francolin Peliperdix coqui (Figure 1) might prefer a mix of low intensity, cultivated commercial fields interspersed with grassland. This increase was especially noticeable around the intersections between North-West, Free State and Gauteng provincial boundaries.

Table 1: Range-change summary for the Coqui francolin between SABAP1 and SABAP2. Numbers (and percentages) in each colour category of Figure 4, for which there are at least four checklists per quarter degree grid cell in both SABAP1 and SABAP2. Also shown are the same summaries when the analysis is restricted to grid cells with at least 30 checklists for both SABAP1 and SABAP2.

\begin{tabular}{lrrrrr}
\hline & \multicolumn{2}{c}{$4+$ checklists } & & \multicolumn{2}{c}{$30+$ checklists } \\
\cline { 2 - 3 } \cline { 5 - 6 } Status & Count & $\%$ & & Count & $\%$ \\
\hline Red (very large decrease) & 208 & 57 & & 129 & 60 \\
Orange (large decrease) & 37 & 10 & & 25 & 12 \\
Yellow (small decrease) & 29 & 8 & & 15 & 7 \\
Light green (small increase) & 10 & 3 & & 6 & 3 \\
Dark green (large increase) & 17 & 5 & & 10 & 5 \\
Blue (very large increase) & 66 & 18 & & 29 & 14 \\
Total & 367 & 100 & & 214 & 100 \\
\hline
\end{tabular}




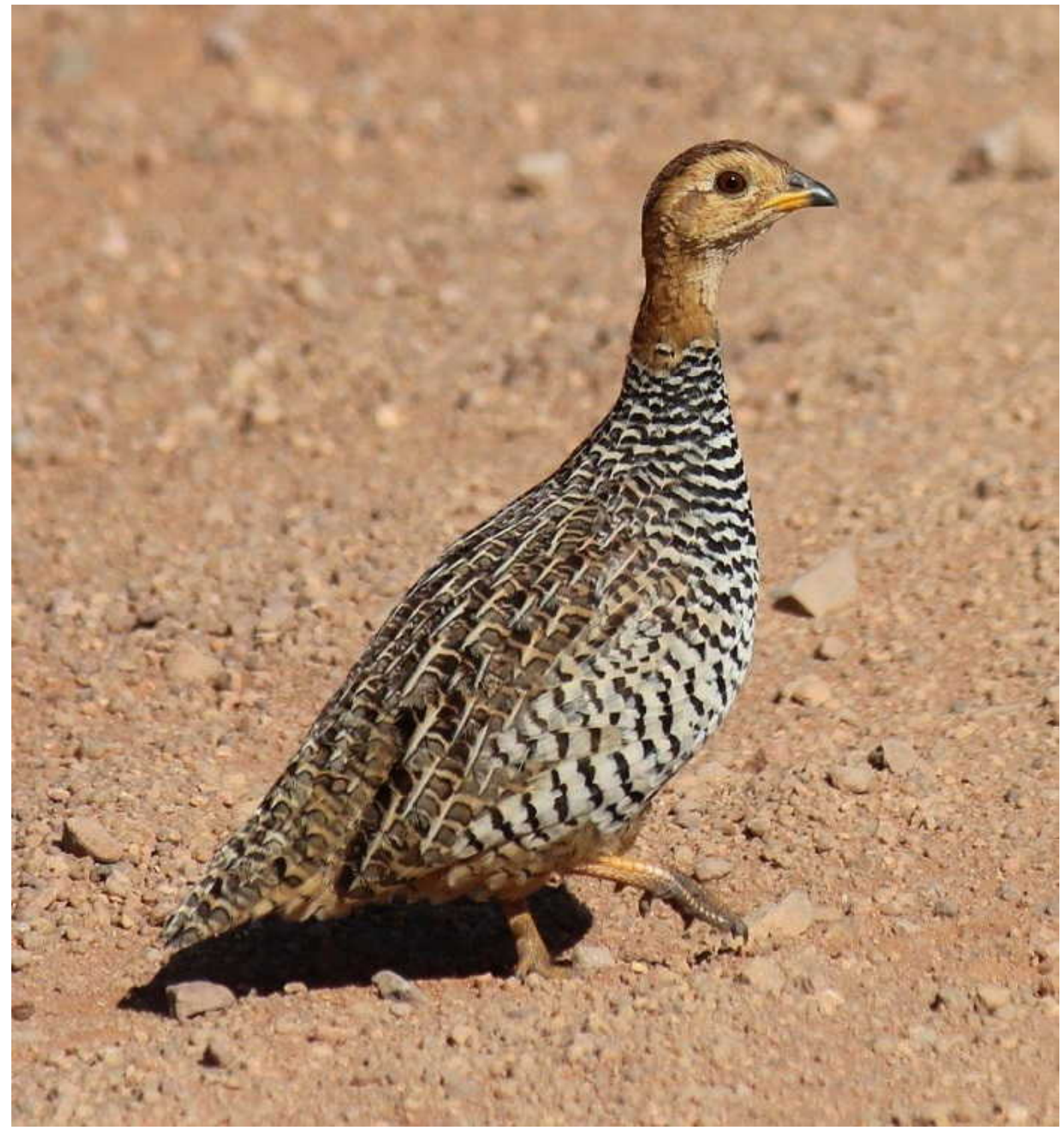

Figure 1: Coqui francolin male, Gauteng Province. Photographer (c) I McCutcheon. Record 27539 in the BirdPix section of the ADU Virtual Museum. Full details available at http:// vmus.adu.org.za/?vm=BirdPix-27539 


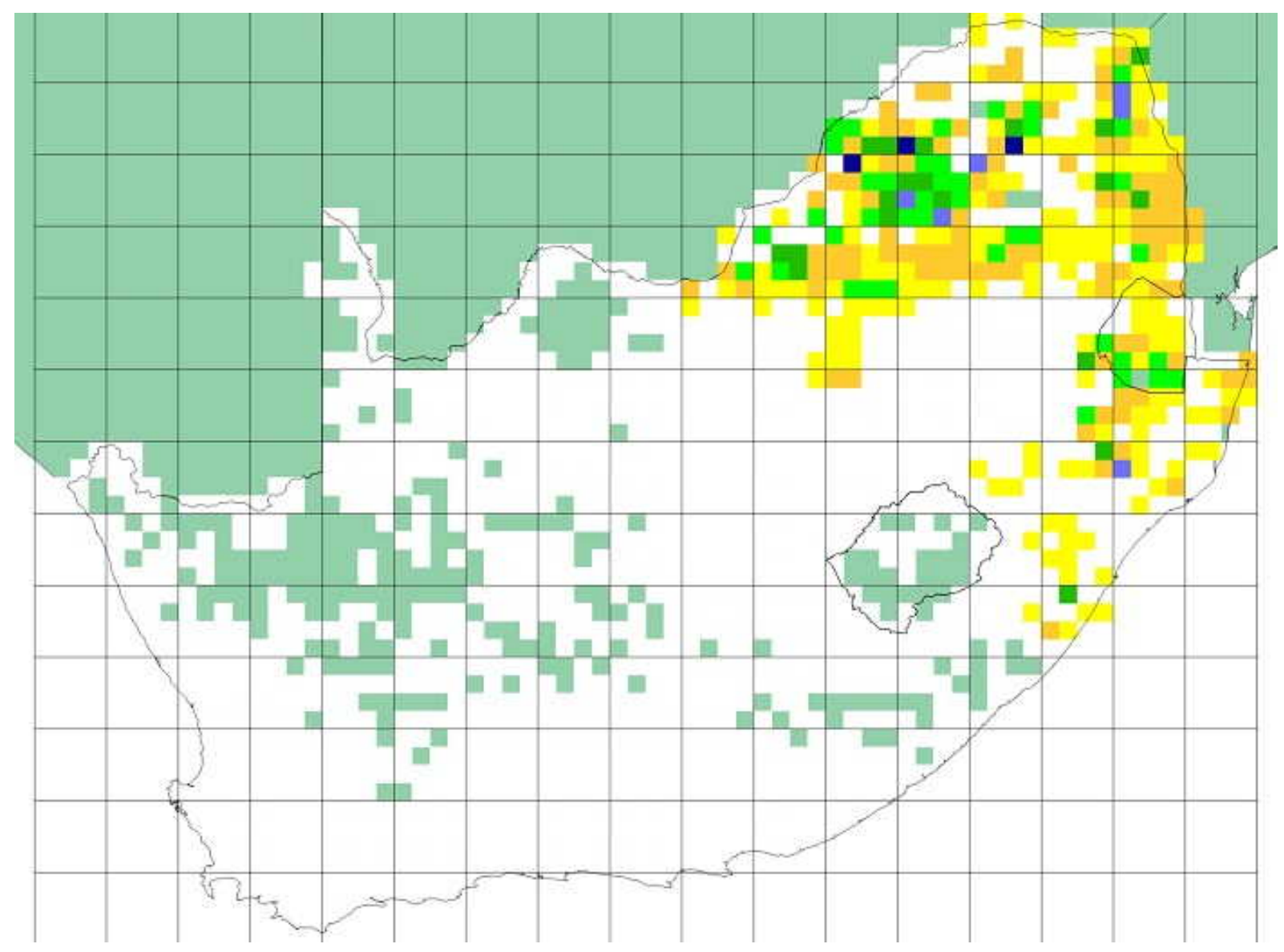

Figure 2: SABAP1 distribution map for the Coqui francolin. Note that quarter degree grid cells shaded turquoise had no SABAP1 data or fewer than four cards submitted (Mozambique, Botswana, Namibia, much of the Northern Cape Province and former Transkei). The colours represent reporting rates, and the cutpoints for the different colours are the same as used for SABAP2, see Figure 3. 


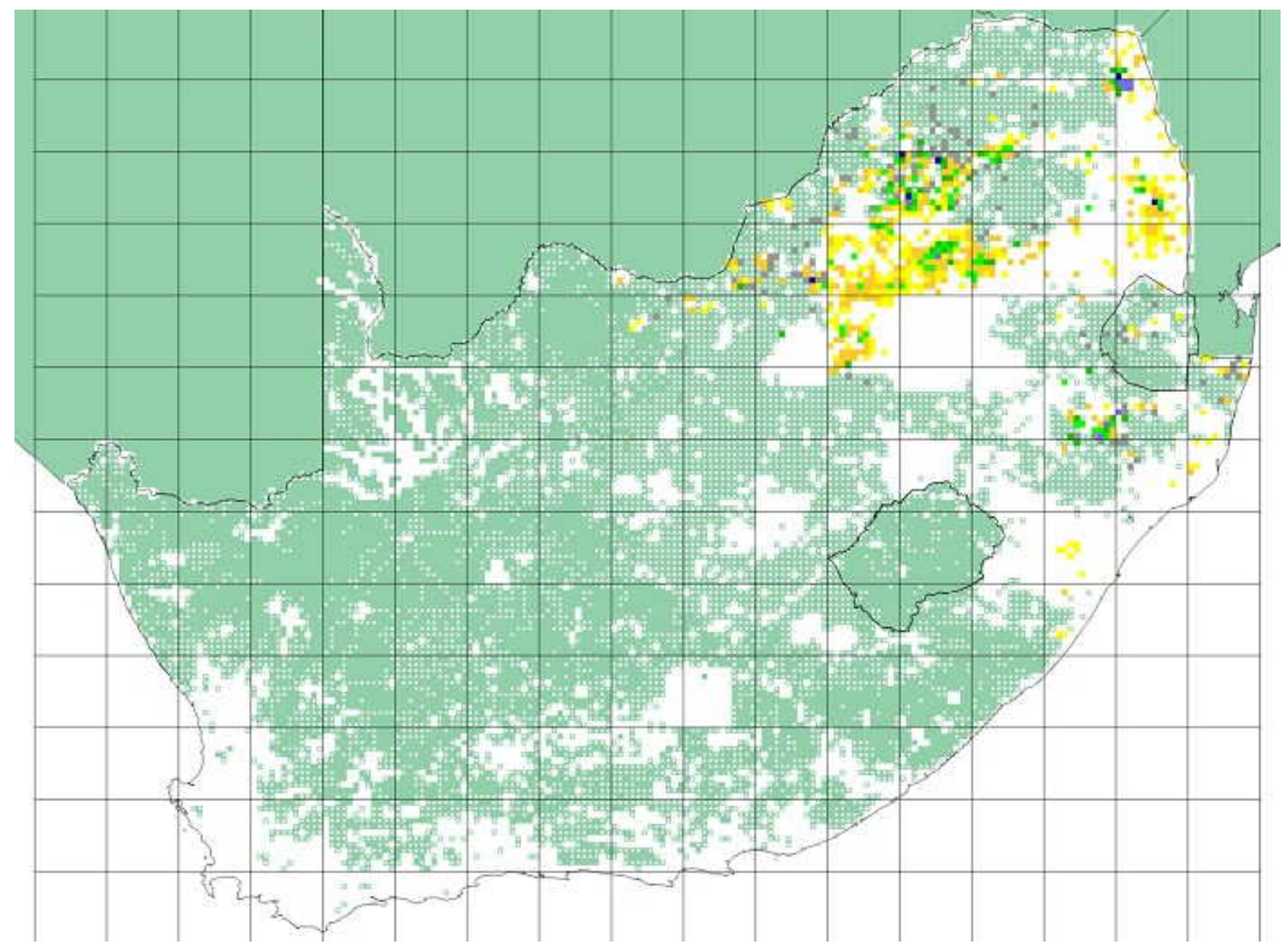

Figure 3: SABAP2 distribution map for the Coqui francolin, downloaded 19 May 2017. The detailed interpretation of this map is provided by Underhill \& Brooks (2016a). Pentads with four or more checklists are either shaded white, species not recorded, or in colour, with shades based on reporting rate: yellow $0-10.2 \%$, orange $10.2-26.3 \%$, light green $26.3-43.3 \%$, dark green 43.3-63.2\%, light blue $63.2-79.2 \%$ and dark blue $79.2-100 \%$. 


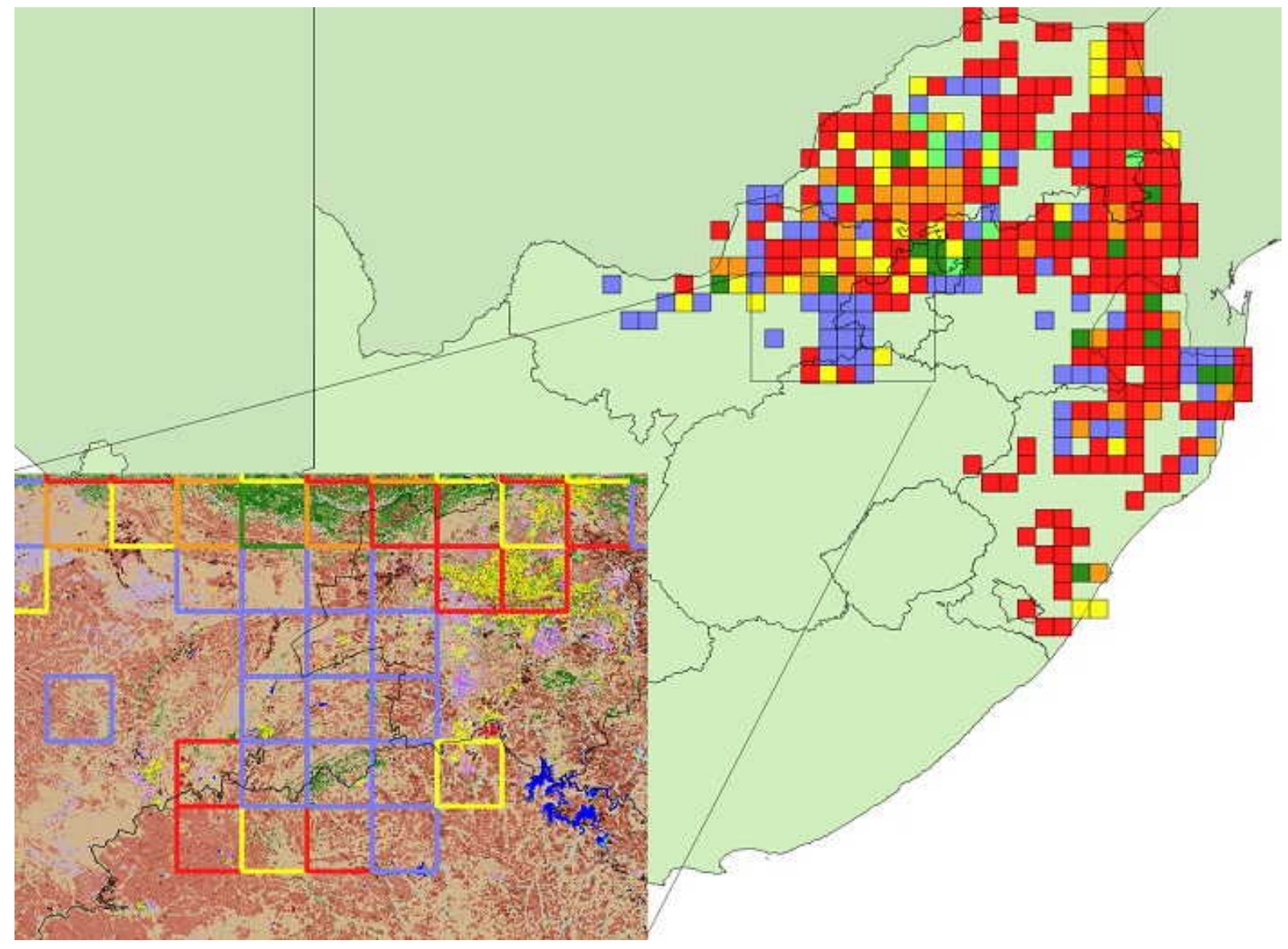

Figure 4: Range-change map between SABAP1 and SABAP2 for the Coqui francolin downloaded 19 May 2017. Red, orange and yellow represent quarter-degree grid cells with very large, large, and small relative decreases and blue, dark green and light green represent grid cells with very large, large and small relative increases. A count of the number of grid cells in each category is provided in Table 1. Only grid cells with at least four checklists in both SABAP1 and SABAP2 are shown. More detailed information on the interpretation of this range-change map is provided in Underhill \& Brooks (2016b). Inset map shows underlying land cover classes (GeoTerra Image 2015) of an area where widespread and large (greenbordered cells) to very large (blue-bordered cells) increases in Coqui francolin occurred. Sandcoloured areas are grassland, coral-coloured areas are low intensity, cultivated commercial fields, green areas are woodland and yellow is depicted as urban areas. The bright blue at the right of the inset map is the Vaal Dam with the Vredefort Dome visible immediately to the West. 


\section{Crested francolin Dendroperdix sephaena}

This species showed approximately equal portions of increases and decreases in its distribution across the northern parts of South Africa (Table 2). Decreases could have been associated across crested francolin Dendroperdix sephaena (Figure 5) distribution to a multitude of land covers including plantations, orchards, thicket, urban areas and high intensity commercial agriculture. The northern half of the Gauteng Province showed increases mostly in urban areas, wooded habitats and low to medium intensity commercial agricultural fields interspersed with grassland (GeoTerra Image, 2015). As with the Coqui francolin, the crested francolin seemed to shift its distribution towards the Kalahari (Westerly) where low shrubland, subsistence and low intensity commercial agriculture and, open woodland form a heterogeneous landscape. This shared preference for habitats with the former species, has been reported before by Little (2005b).

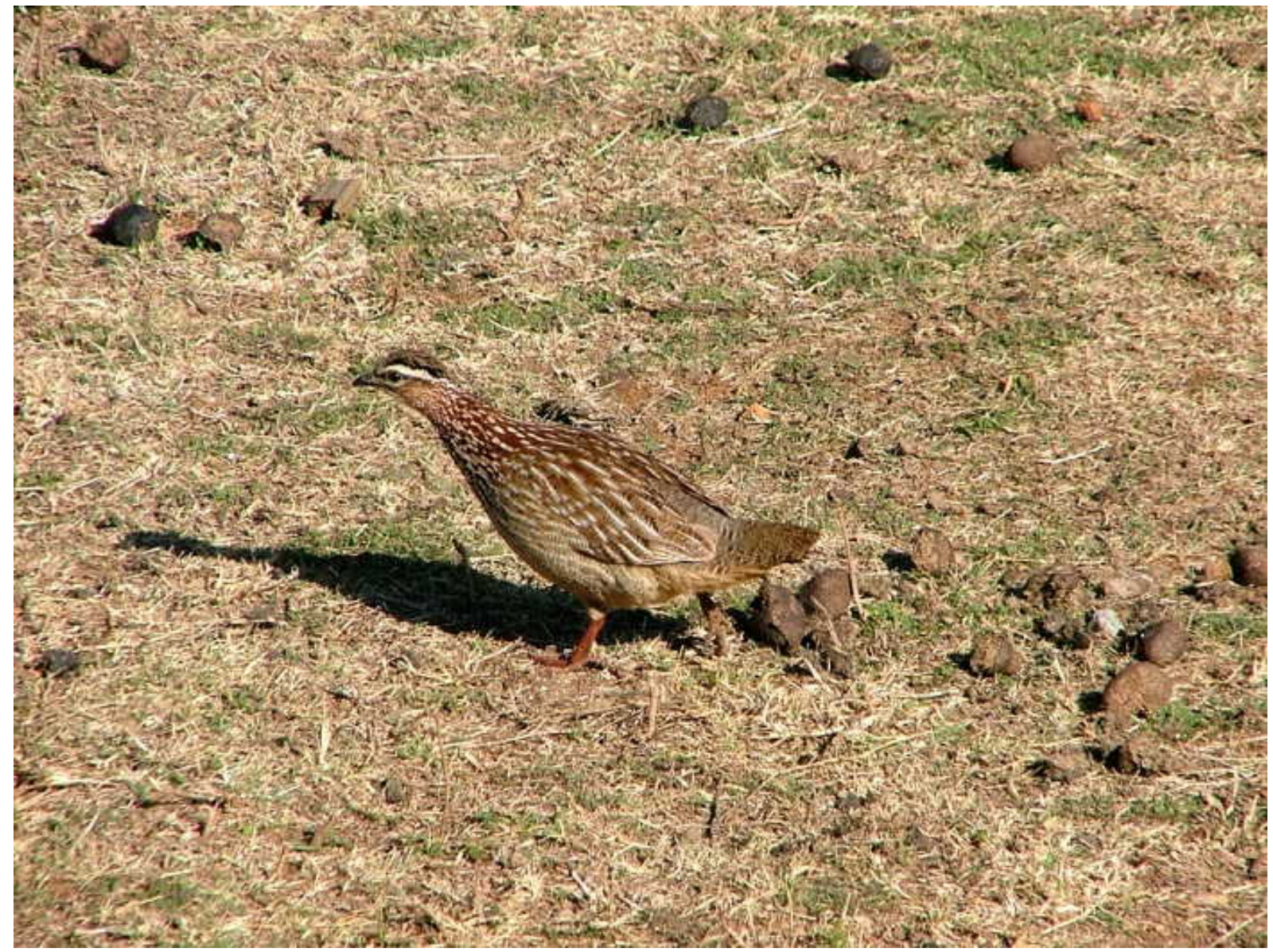

Figure 5: Crested francolin, North-West Province. Photographer (C) D Kennedy. Record 5159 in the BirdPix section of the ADU Virtual Museum. Full details available at http://vmus.adu. org.za/?vm=BirdPix-5159 


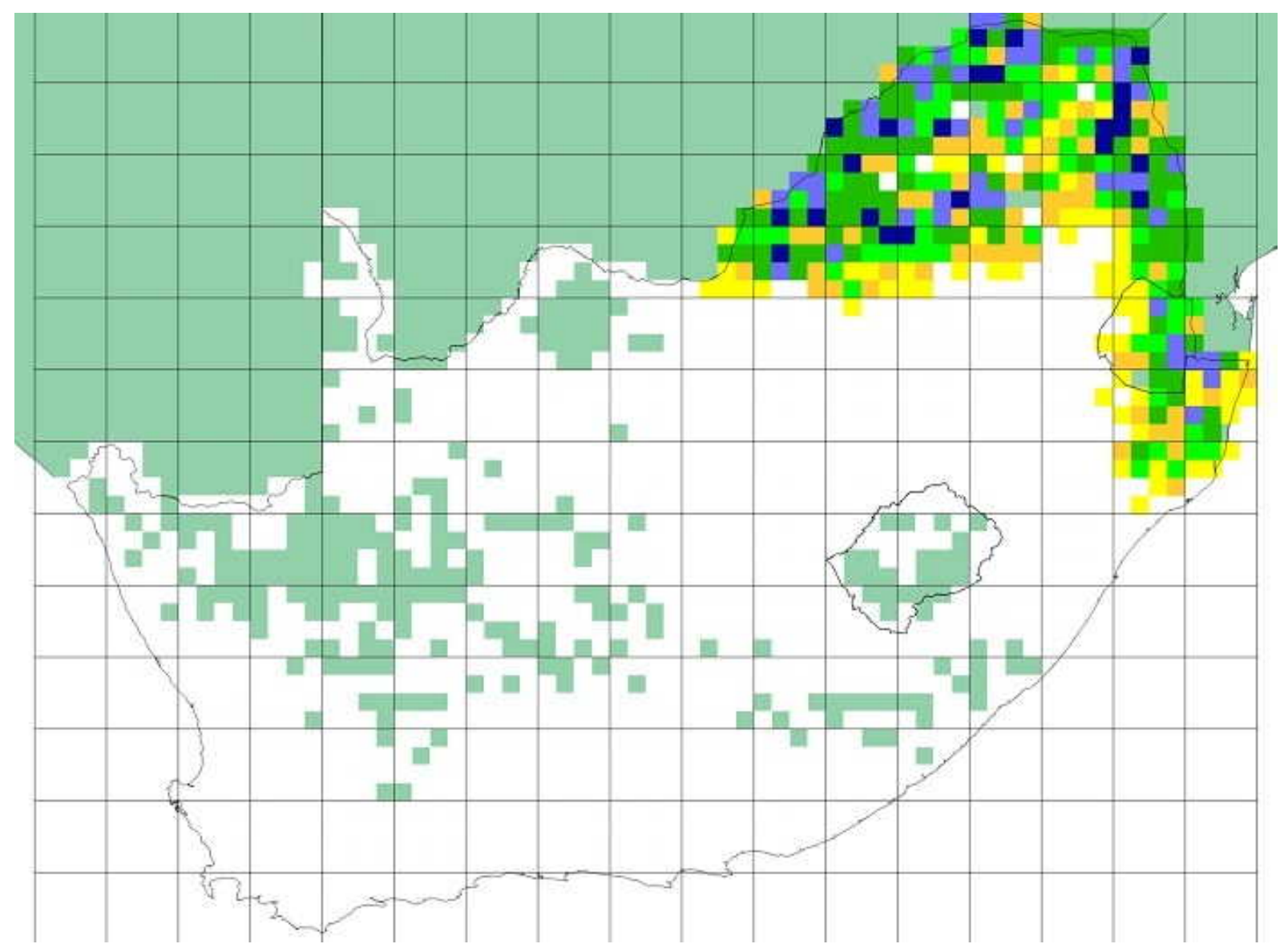

Figure 6: SABAP1 distribution map for the crested francolin. Note that quarter degree grid cells shaded turquoise had no SABAP1 data or fewer than four cards submitted (Mozambique, Botswana, Namibia, much of the Northern Cape Province and former Transkei). The colours represent reporting rates, and the cutpoints for the different colours are the same as used for SABAP2, see Figure 7. 


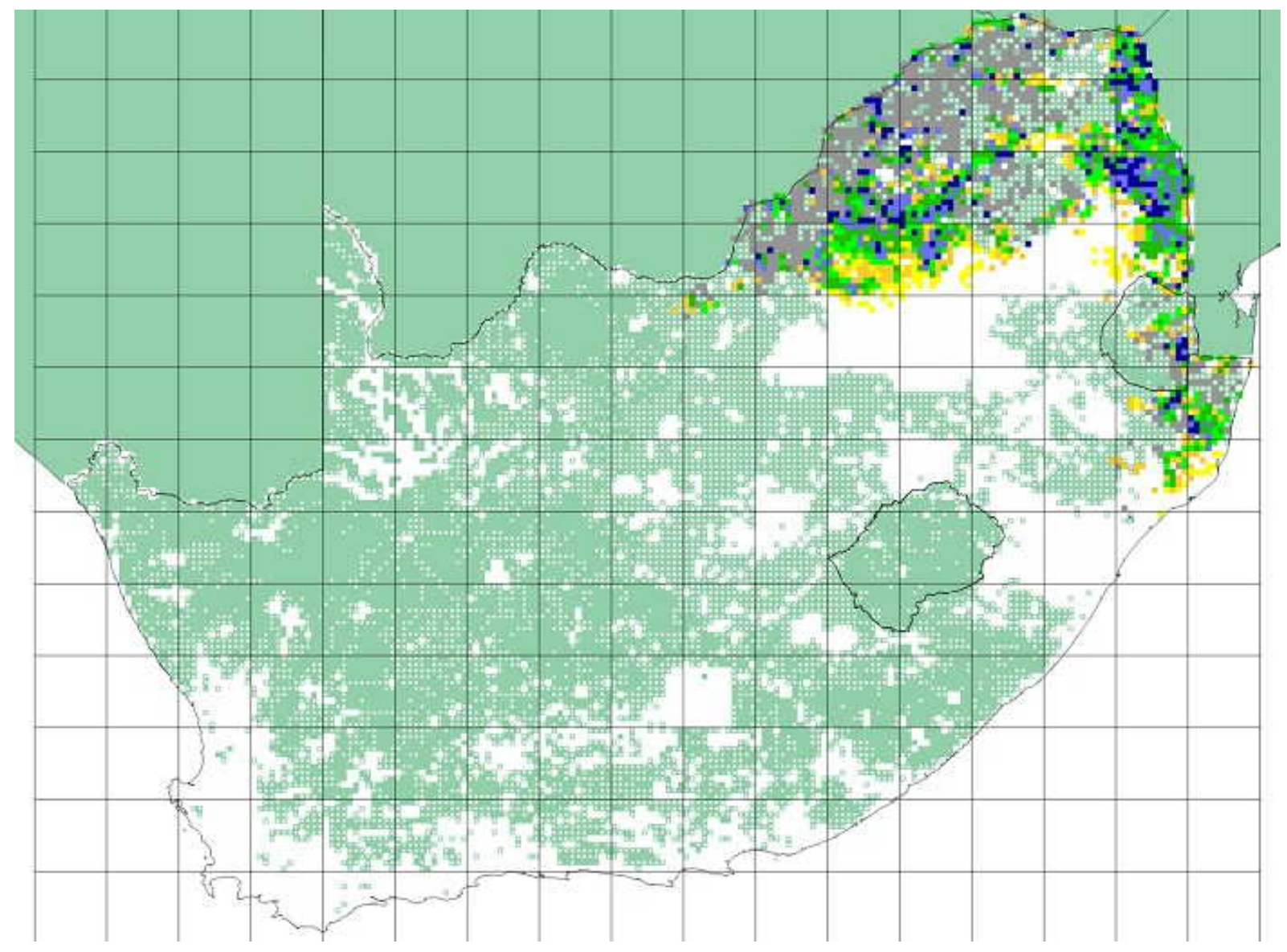

Figure 7: SABAP2 distribution map for the crested francolin, downloaded 19 May 2017. The detailed interpretation of this map is provided by Underhill \& Brooks (2016a). Pentads with four or more checklists are either shaded white, species not recorded, or in colour, with shades based on reporting rate: yellow $0-10.2 \%$, orange $10.2-26.3 \%$, light green $26.3-43.3 \%$, dark green 43.3-63.2\%, light blue 63.2-79.2\% and dark blue $79.2-100 \%$. 


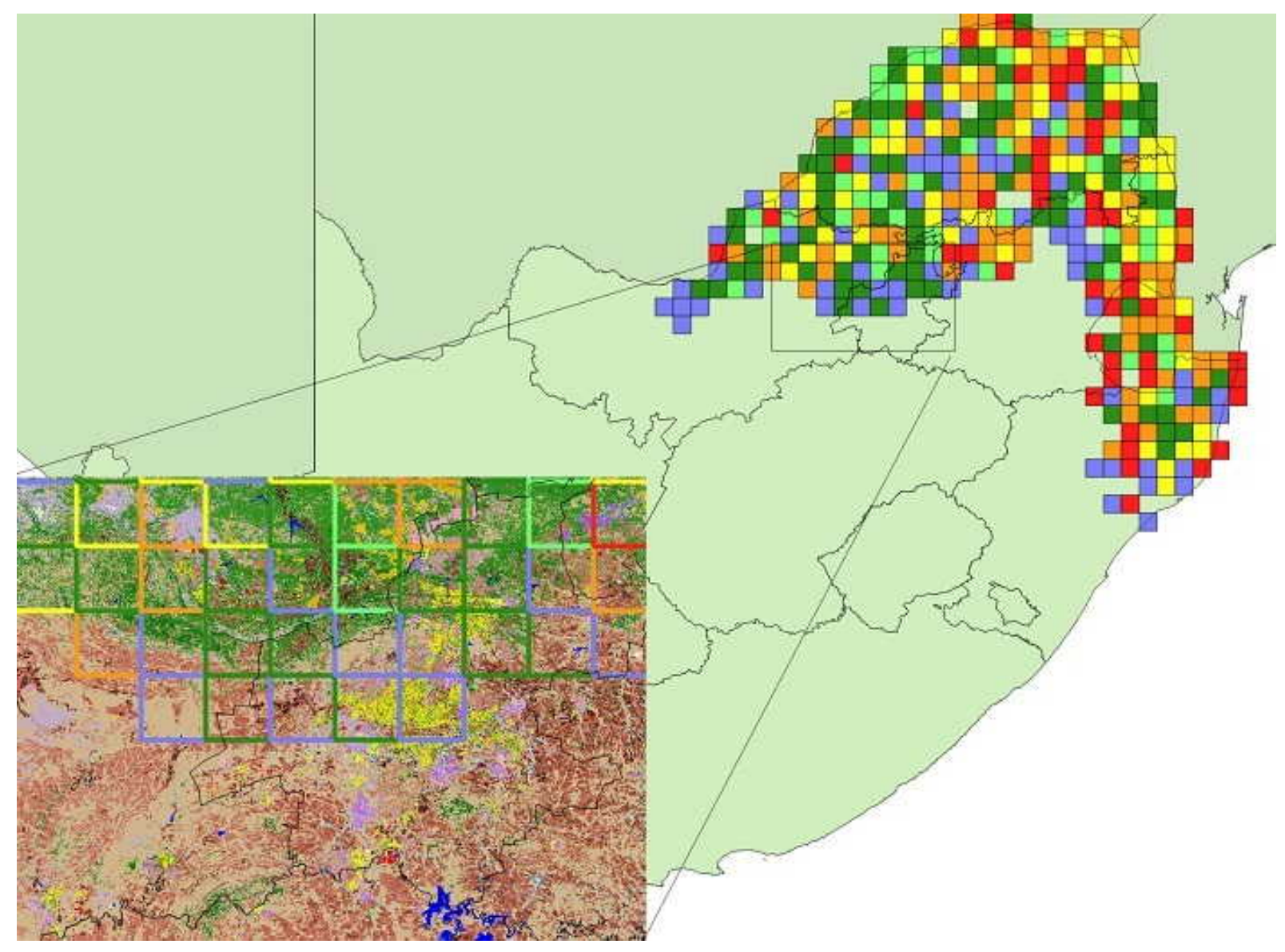

Figure 8: Range-change map between SABAP1 and SABAP2 for the crested francolin downloaded 19 May 2017. Red, orange and yellow represent quarter-degree grid cells with very large, large, and small relative decreases and blue, dark green and light green represent grid cells with very large, large and small relative increases. A count of the number of grid cells in each category is provided in Table 2. Only grid cells with at least four checklists in both SABAP1 and SABAP2 are shown. More detailed information on the interpretation of this range-change map is provided in Underhill \& Brooks (2016b). Inset map shows underlying land cover classes (GeoTerra Image 2015) of an area where widespread and large (greenbordered cells) to very large (blue-bordered cells) increases in crested francolin occurred. Sandcoloured areas are grassland, coral to brown-coloured areas are cultivated commercial fields, green areas are woodland and yellow and purple are depicted as urban areas. 
Table 2: Range-change summary for the crested francolin between SABAP1 and SABAP2. Numbers (and percentages) in each colour category of Figure 8, for which there are at least four checklists per quarter degree grid cell in both SABAP1 and SABAP2. Also shown are the same summaries when the analysis is restricted to grid cells with at least 30 checklists for both SABAP1 and SABAP2.

\begin{tabular}{lrrrrr}
\hline & \multicolumn{2}{c}{$4+$ checklists } & & \multicolumn{2}{c}{ 30+ checklists } \\
\cline { 2 - 3 } \cline { 5 - 6 } Status & Count & $\%$ & & Count & $\%$ \\
\hline Red (very large decrease) & 49 & 13 & & 18 & 10 \\
Orange (large decrease) & 75 & 20 & & 43 & 23 \\
Yellow (small decrease) & 61 & 16 & & 35 & 19 \\
Light green (small increase) & 45 & 12 & & 24 & 13 \\
Dark green (large increase) & 81 & 21 & & 32 & 17 \\
Blue (very large increase) & 67 & 18 & & 32 & 17 \\
Total & 378 & 100 & & 184 & 100 \\
\hline
\end{tabular}

\section{Grey-winged francolin Scleroptila africanus}

Very large decreases were visible across the 'Cape provinces' and KwaZulu-Natal (46-51\% cells where the species was recorded; Figure 12; Table 3). In the Western Cape Province these areas were characterised by GeoTerra Image (2015) as high intensity cultivated commercial fields, vineyards and urbanisation with increases towards the North into the Karoo's low shrubland and bare soils (Figure 12). The decreases elsewhere across the Eastern Cape and KwaZuluNatal seemed to be in areas where sparse commercial cultivated fields of low intensity or plantations/woodland were present. The largest increases in distribution for grey-winged francolin Scleroptila africanus (Figure 9) was distributed across the boundaries of the Free State and Mpumalanga Provinces of South Africa. Here, high-density commercial cultivated fields of low to medium intensity, dominated the historically grassland landscape. What the GeoTerra Image remote sensing product could not tell us was whether domestic livestock grazing has impacted on changes in distribution of this species. We may only assume that remnant grasslands where decreases took place across the Mpumalanga Province are associated with livestock (Jansen $e t$ al. 1999).

Table 3: Range-change summary for the grey-winged francolin between SABAP1 and SABAP2. Numbers (and percentages) in each colour category of Figure 12, for which there are at least four checklists per quarter degree grid cell in both SABAP1 and SABAP2. Also shown are the same summaries when the analysis is restricted to grid cells with at least 30 checklists for both SABAP1 and SABAP2.

\begin{tabular}{lrrrrr}
\hline & \multicolumn{2}{c}{$4+$ checklists } & & \multicolumn{2}{c}{$30+$ checklists } \\
\cline { 2 - 3 } \cline { 5 - 6 } Status & Count & $\%$ & & Count & $\%$ \\
\hline Red (very large decrease) & 263 & 46 & & 141 & 51 \\
Orange (large decrease) & 76 & 13 & & 50 & 18 \\
Yellow (small decrease) & 42 & 7 & & 22 & 8 \\
Light green (small increase) & 29 & 5 & & 13 & 5 \\
Dark green (large increase) & 34 & 6 & & 10 & 4 \\
Blue (very large increase) & 128 & 22 & & 43 & 15 \\
Total & 572 & 100 & & 279 & 100 \\
\hline
\end{tabular}




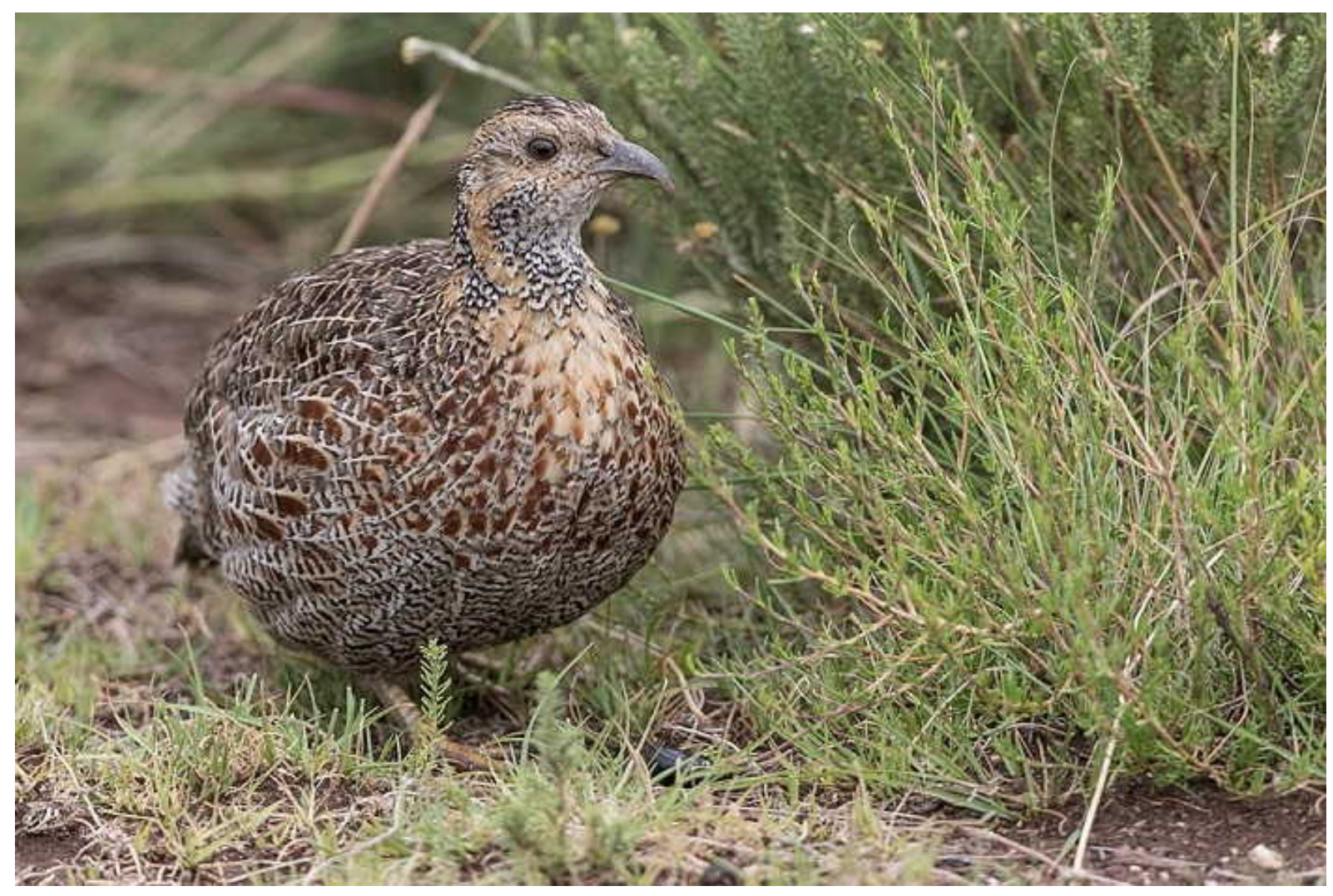

Figure 9: Grey-winged francolin, Eastern Cape Province. Photographers (C) G and D Darling. Record 33282 in the BirdPix section of the ADU Virtual Museum. Full details available at http: / /vmus.adu.org.za/?vm=BirdPix-33282 


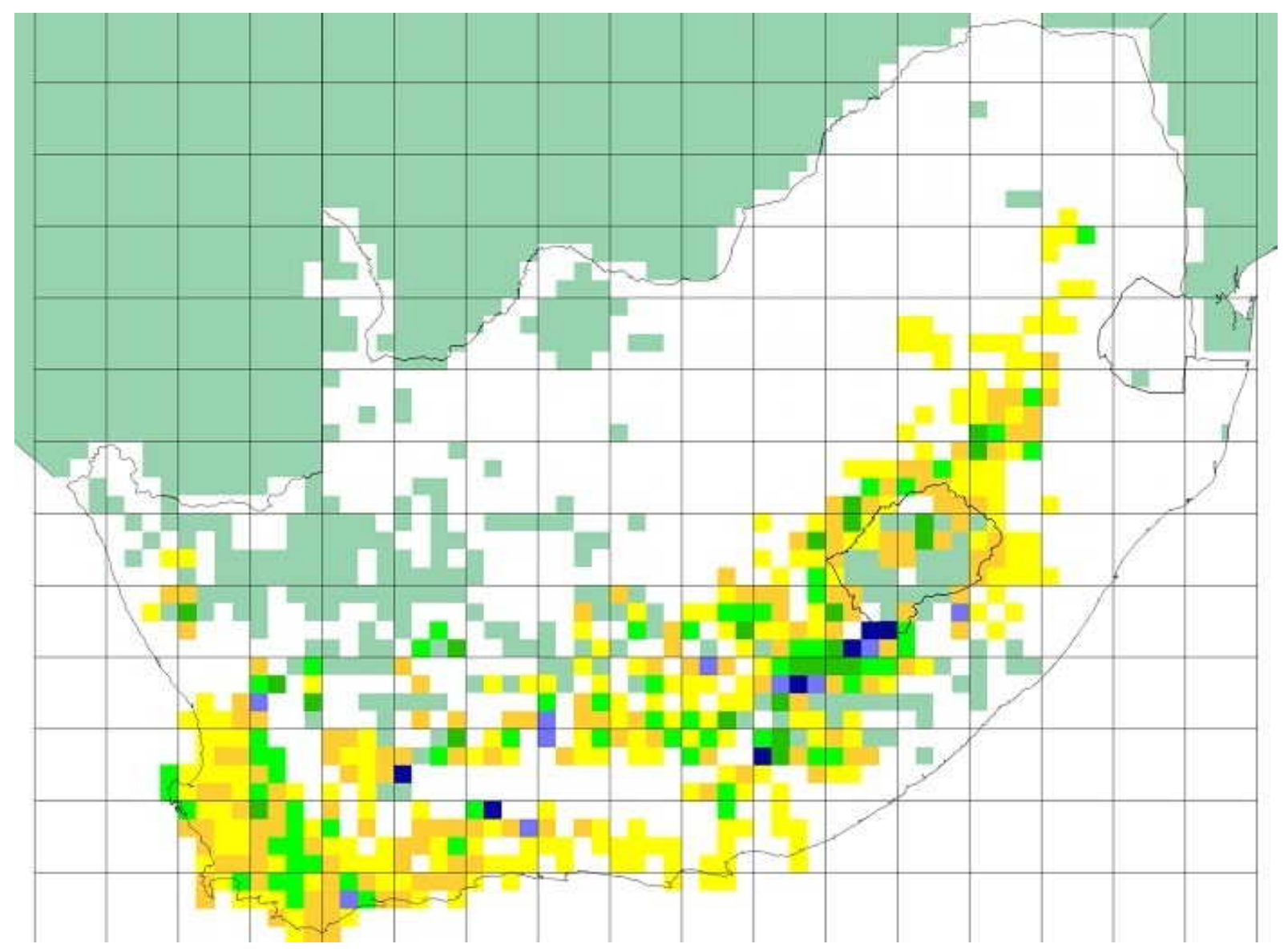

Figure 10: SABAP1 distribution map for the grey-winged francolin. Note that quarter degree grid cells shaded turquoise had no SABAP1 data or fewer than four cards submitted (Mozambique, Botswana, Namibia, much of the Northern Cape province and former Transkei). The colours represent reporting rates, and the cutpoints for the different colours are the same as used for SABAP2, see Figure 11. 


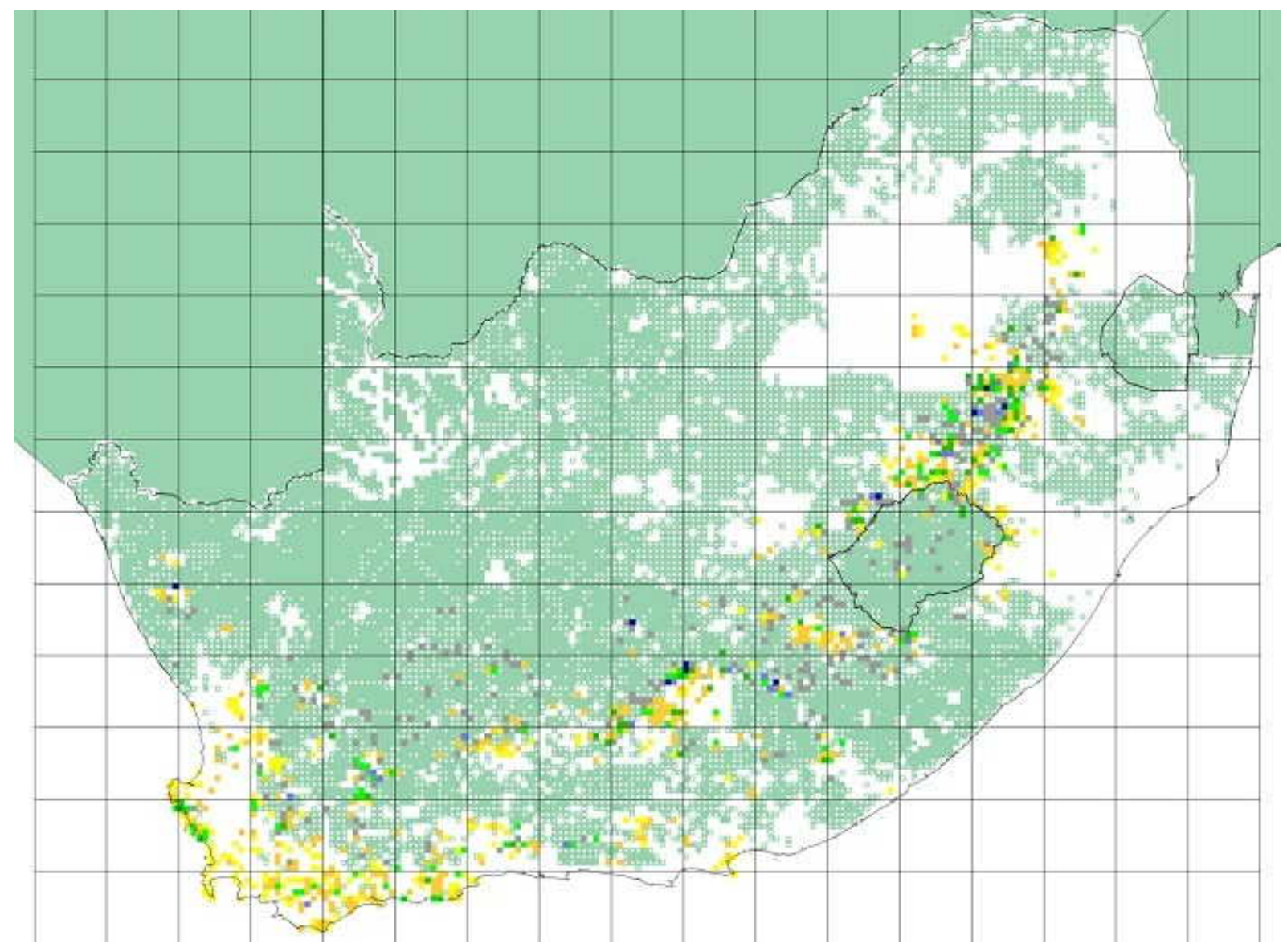

Figure 11: SABAP2 distribution map for the grey-winged francolin, downloaded 19 May 2017. The detailed interpretation of this map is provided by Underhill \& Brooks (2016a). Pentads with four or more checklists are either shaded white, species not recorded, or in colour, with shades based on reporting rate: yellow $0-10.2 \%$, orange $10.2-26.3 \%$, light green $26.3-43.3 \%$, dark green $43.3-63.2 \%$, light blue $63.2-79.2 \%$ and dark blue $79.2-100 \%$. 


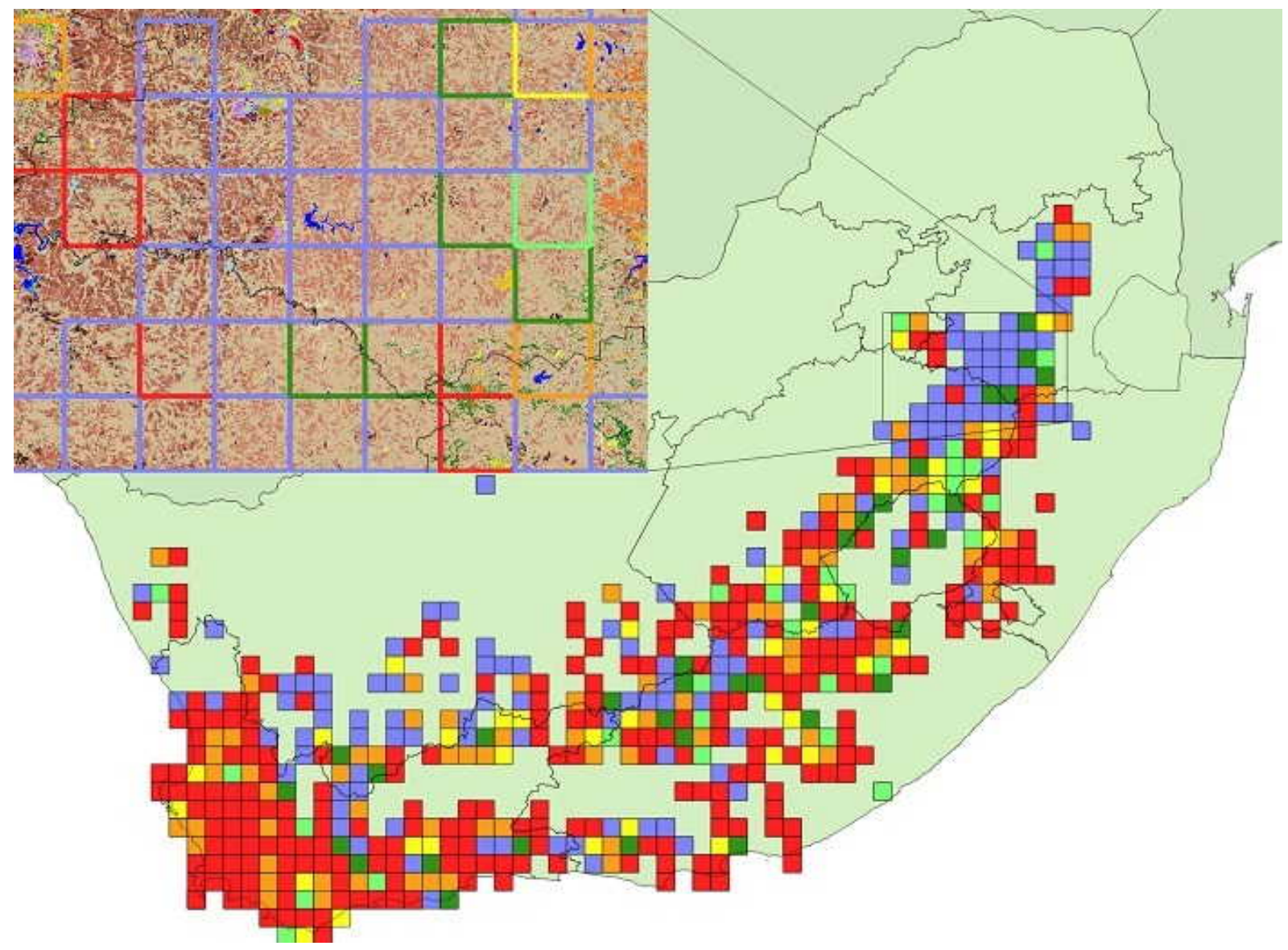

Figure 12: Range-change map between SABAP1 and SABAP2 for the grey-winged francolin downloaded 19 May 2017. Red, orange and yellow represent quarter-degree grid cells with very large, large, and small relative decreases and blue, dark green and light green represent grid cells with very large, large and small relative increases. A count of the number of grid cells in each category is provided in Table 3. Only grid cells with at least four checklists in both SABAP1 and SABAP2 are shown. More detailed information on the interpretation of this range-change map is provided in Underhill \& Brooks (2016b). Inset map shows underlying land cover classes (GeoTerra Image 2015) of an area where widespread and large (greenbordered cells) to very large (blue-bordered cells) increases in grey-winged francolin occurred. Sand-coloured areas are grassland, coral to brown-coloured areas are cultivated commercial fields, green areas are woodland and yellow and purple are depicted as urban areas. 


\section{Shelley's francolin Scleroptila shelleyi}

Across this species' distribution range, widespread and very large decreases were evident since the first SABAP (Figure 16). These contiguous areas of decreased reporting rates such as central to north-eastern Mpumalanga, contained massive areas under exotic plantations and dense woodland or thicket (GeoTerra Image 2015). Other land covers appearing within these quarter degree grid cells are grasslands interspersed with woodland, plantations and orchards. Northern Kruger National Park also showed widespread but, very large decreases since SABAP1 and these were characterised by contiguous patches of thicket or denser woodland with some very large increases where grassland was more dominant towards the central parts of the park. Western KwaZulu-Natal showed the largest contiguous area of very large increases since SABAP1 (Figure 16). Here, a mosaic of land cover classes was evident across the grid cells where grassland dominated but with some areas covered by urbanisation (formal and informal), villages, medium intensity agriculture and woodland. Across South Africa, areas containing at least some grassland patches among woodland showed to host more Shelley's francolin Scleroptila shelleyi (Figure 13) than other areas, as reported before by Little (2005c).

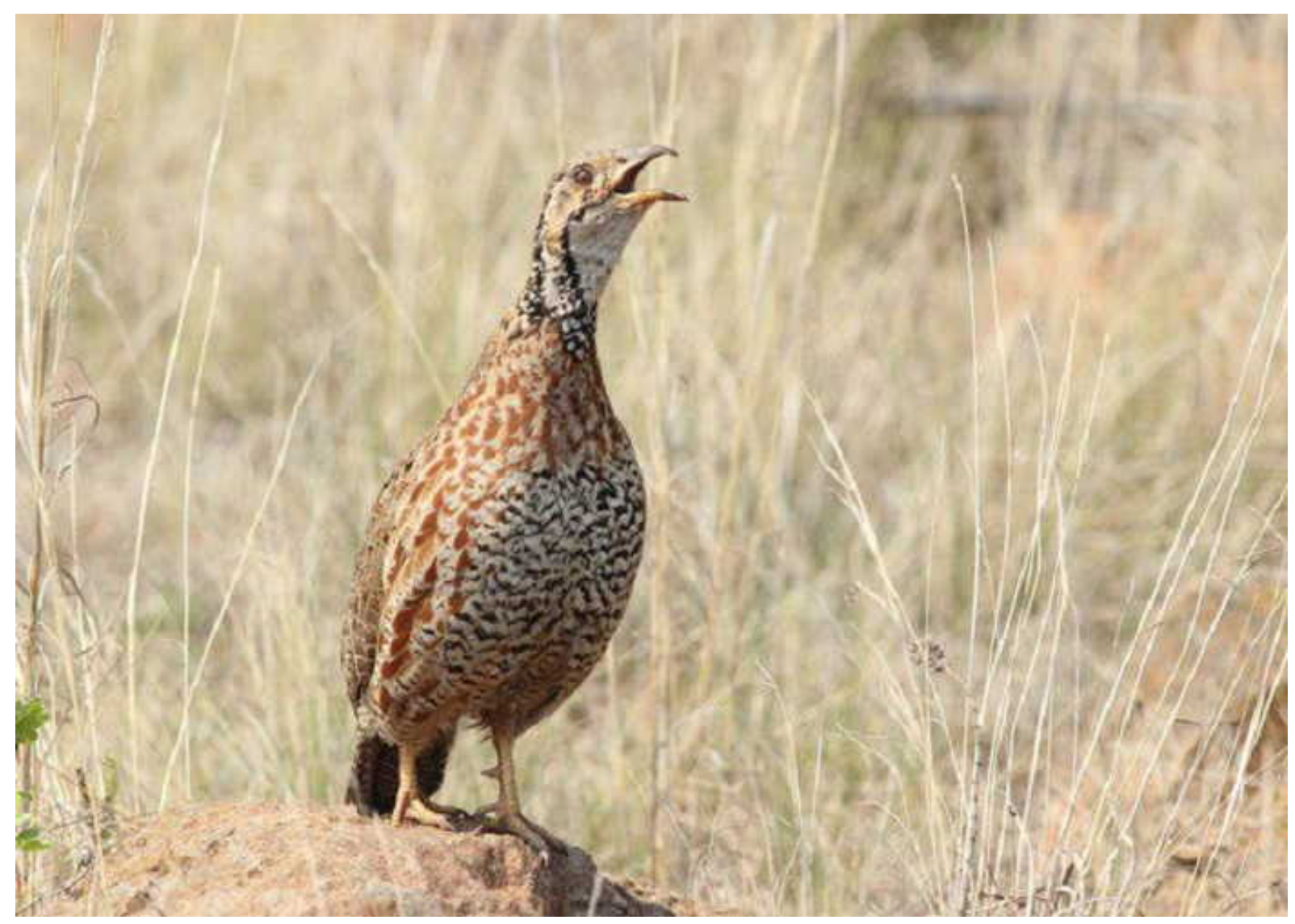

Figure 13: Shelley's francolin calling, KwaZulu-Natal Province. Photographer (C) M Booysen. Record 10358 in the BirdPix section of the ADU Virtual Museum. Full details available at http: //vmus.adu.org.za/?vm=BirdPix-10358 


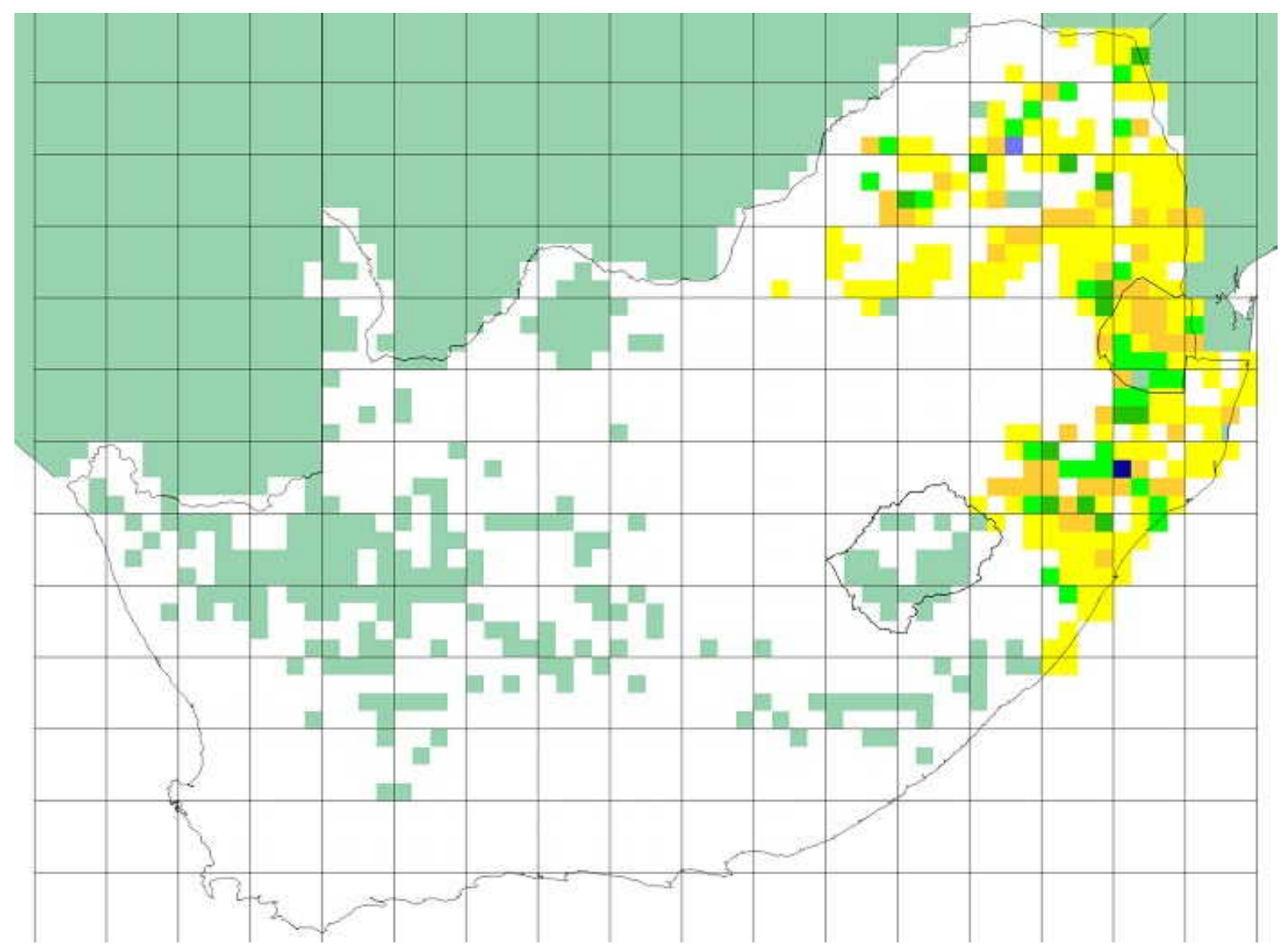

Figure 14: SABAP1 distribution map for the Shelley's francolin. Note that quarter degree grid cells shaded turquoise had no SABAP1 data or fewer than four cards submitted (Mozambique, Botswana, Namibia, much of the Northern Cape Province and former Transkei). The colours represent reporting rates, and the cutpoints for the different colours are the same as used for SABAP2, see Figure 15. 


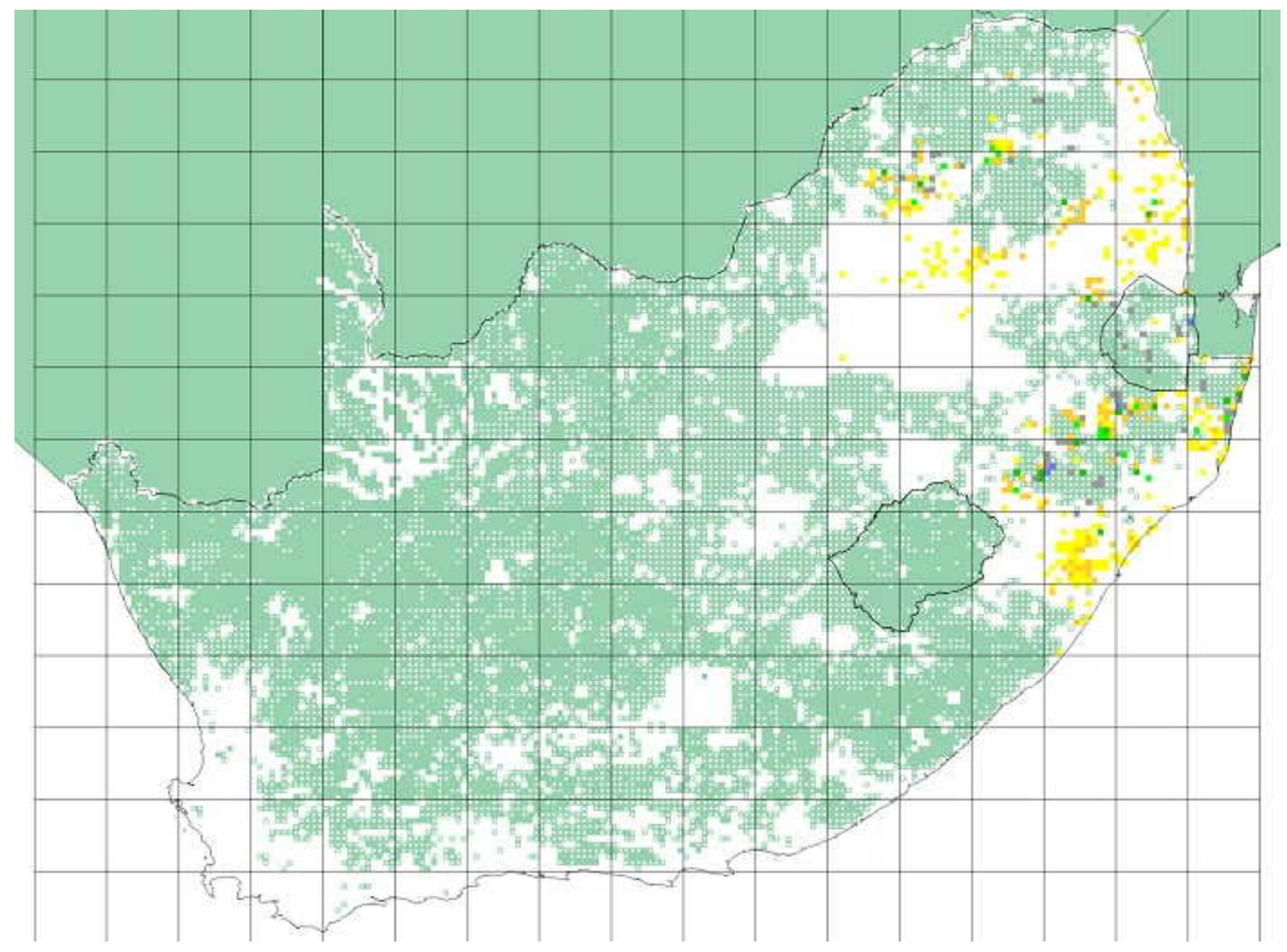

Figure 15: SABAP2 distribution map for the Shelley's francolin, downloaded 19 May 2017. The detailed interpretation of this map is provided by Underhill \& Brooks (2016a). Pentads with four or more checklists are either shaded white, species not recorded, or in colour, with shades based on reporting rate: yellow $0-10.2 \%$, orange $10.2-26.3 \%$, light green $26.3-43.3 \%$, dark green 43.3-63.2\%, light blue 63.2-79.2\% and dark blue $79.2-100 \%$. 


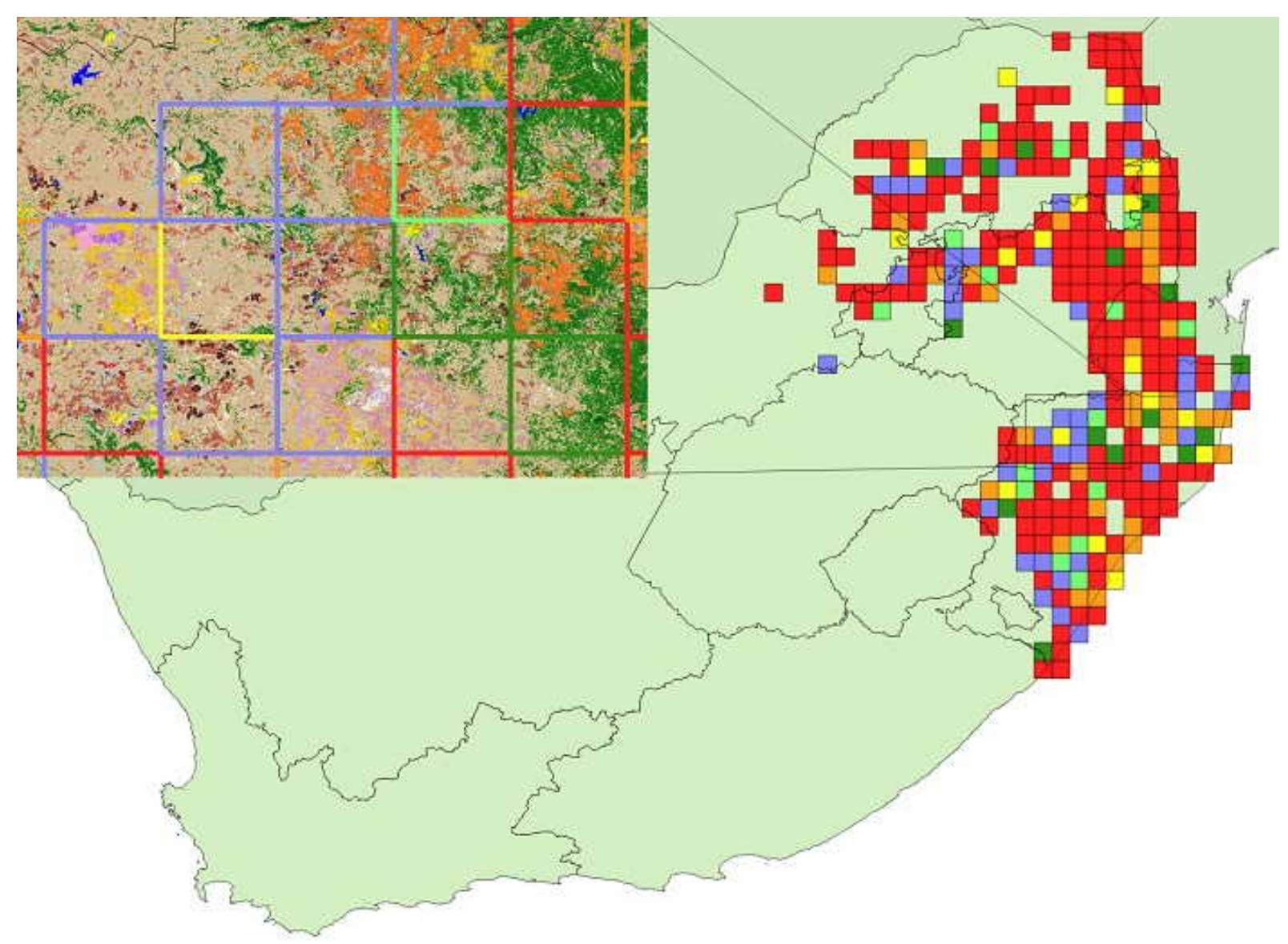

Figure 16: Range-change map between SABAP1 and SABAP2 for the Shelley's francolin downloaded 19 May 2017. Red, orange and yellow represent quarter-degree grid cells with very large, large, and small relative decreases and blue, dark green and light green represent grid cells with very large, large and small relative increases. A count of the number of grid cells in each category is provided in Table 4 . Only grid cells with at least four checklists in both SABAP1 and SABAP2 are shown. More detailed information on the interpretation of this range-change map is provided in Underhill \& Brooks (2016b). Inset map shows underlying complex mosaic of land cover classes (GeoTerra Image 2015) of an area where large (greenbordered cells) to very large (blue-bordered cells) increases in Shelley's francolin occurred. Sand-coloured areas are grassland, coral to brown-coloured areas are cultivated commercial fields, green areas are woodland and yellow and purple are depicted as urban areas. Orange areas are exotic plantations and dull pink-purple are subsistence agriculture around urban villages (yellow). 
Table 4: Range-change summary for the Shelley's francolin between SABAP1 and SABAP2. Numbers (and percentages) in each colour category of Figure 16, for which there are at least four checklists per quarter degree grid cell in both SABAP1 and SABAP2. Also shown are the same summaries when the analysis is restricted to grid cells with at least 30 checklists for both SABAP1 and SABAP2.

\begin{tabular}{lrrrrr}
\hline & \multicolumn{2}{c}{$4+$ checklists } & & \multicolumn{2}{c}{$30+$ checklists } \\
\cline { 2 - 3 } \cline { 5 - 6 } Status & Count & $\%$ & & Count & $\%$ \\
\hline Red (very large decrease) & 179 & 59 & & 122 & 59 \\
Orange (large decrease) & 34 & 11 & & 27 & 13 \\
Yellow (small decrease) & 18 & 6 & & 12 & 6 \\
Light green (small increase) & 15 & 5 & & 10 & 5 \\
Dark green (large increase) & 15 & 5 & & 12 & 6 \\
Blue (very large increase) & 42 & 14 & & 25 & 12 \\
Total & 303 & 100 & & 208 & 100 \\
\hline
\end{tabular}

\section{Red-winged francolin Scleroptila levaillantii}

A species sensitive to overgrazing and frequent burning, the effects of these land-use practices result in local population collapses due to changes in habitat quality and quantity (Jansen et al. 1999; Jansen et al. 2000; Jansen et al. 2001). Where the uKhahlamba-Drakensberg Park, KwaZulu-Natal Province used to be a South African stronghold for red-winged francolin Scleroptila levaillantii (Figure 17, 18; Little 2005), SABAP range-change data showed that large to very large decreases took place since 1991. However, very large decreases in grid cells were widespread and clustered across the species' relatively small South African distribution (Table 5). Generally, land covers such as dense commercial agriculture of various intensity and bare mines among grasslands were areas that showed the largest decreases (Figure 20). Along the eastern to southern coast of South Africa and down to the Western Cape, thicket, woodland, exotic plantations, high intensity commercial agriculture and urbanisation seemed to drive lowered reporting rates. Across central Mpumalanga, large to very large increases in distribution seemed to be associated with the same land covers where large decreases (Free State, South-Western Mpumalanga and Eastern Cape) took place except for the lowered agricultural intensity that dominated this area of increased reports. A possibility for this anomaly might be increased livestock grazing in provinces where very large decreases were seen. As mentioned before, grazing intensity on grassland systems could not be identified using GeoTerra Image (2015) remote sensing product and may well be a confounding factor in some of the grassland-covered areas. The land cover dataset also does not show burnt areas hence, these two important components driving red-winged francolin populations might well have been the cause of country-wide declines, especially across the interior of South Africa where livestock grazing is prominent. 


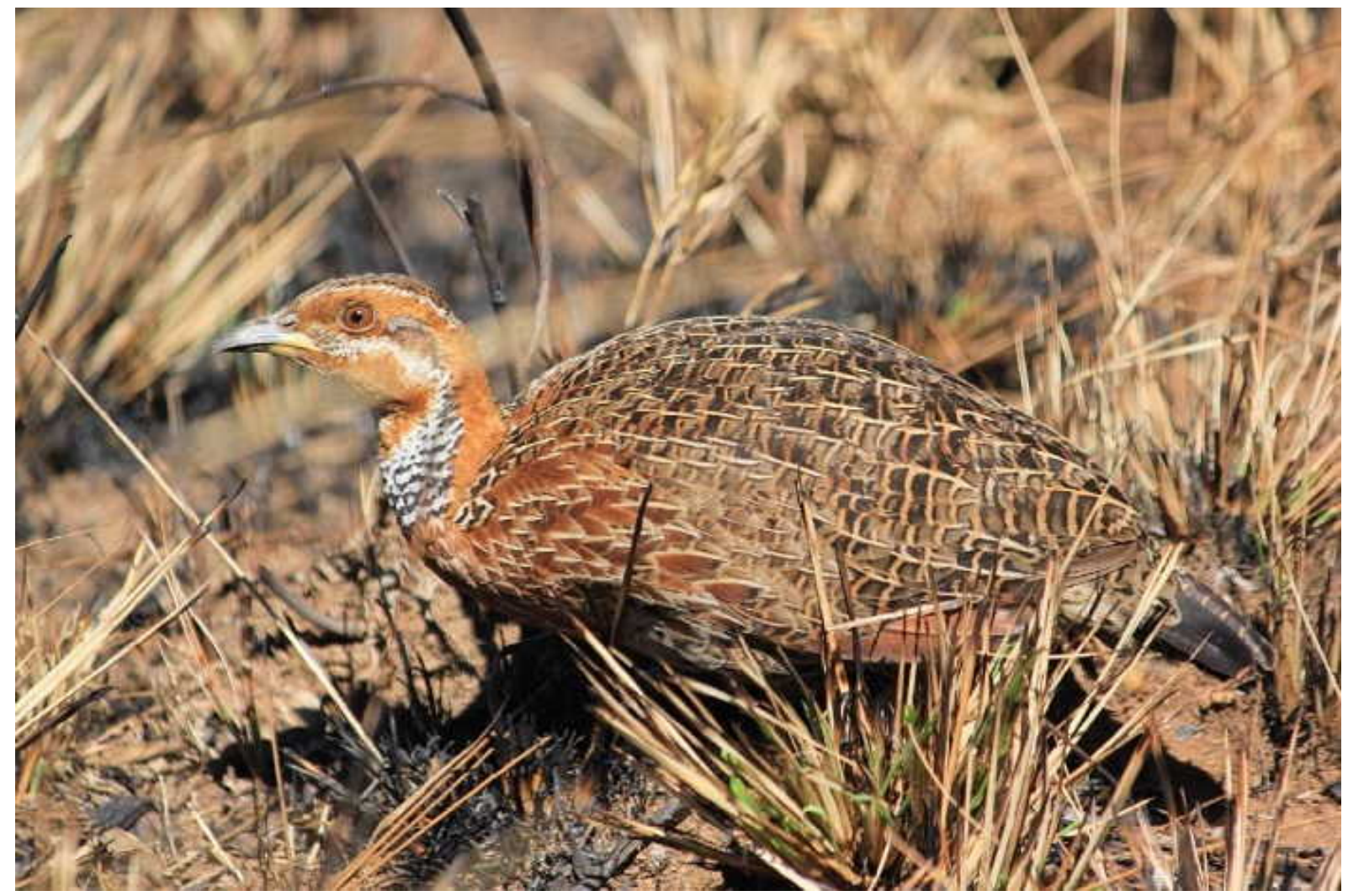

Figure 17: Red-winged francolin, Malawi. Photographers (C) G, C and F Brown. Record 2949 in the BirdPix section of the ADU Virtual Museum. Full details available at http://vmus.adu. org.za/?vm=BirdPix-2949 


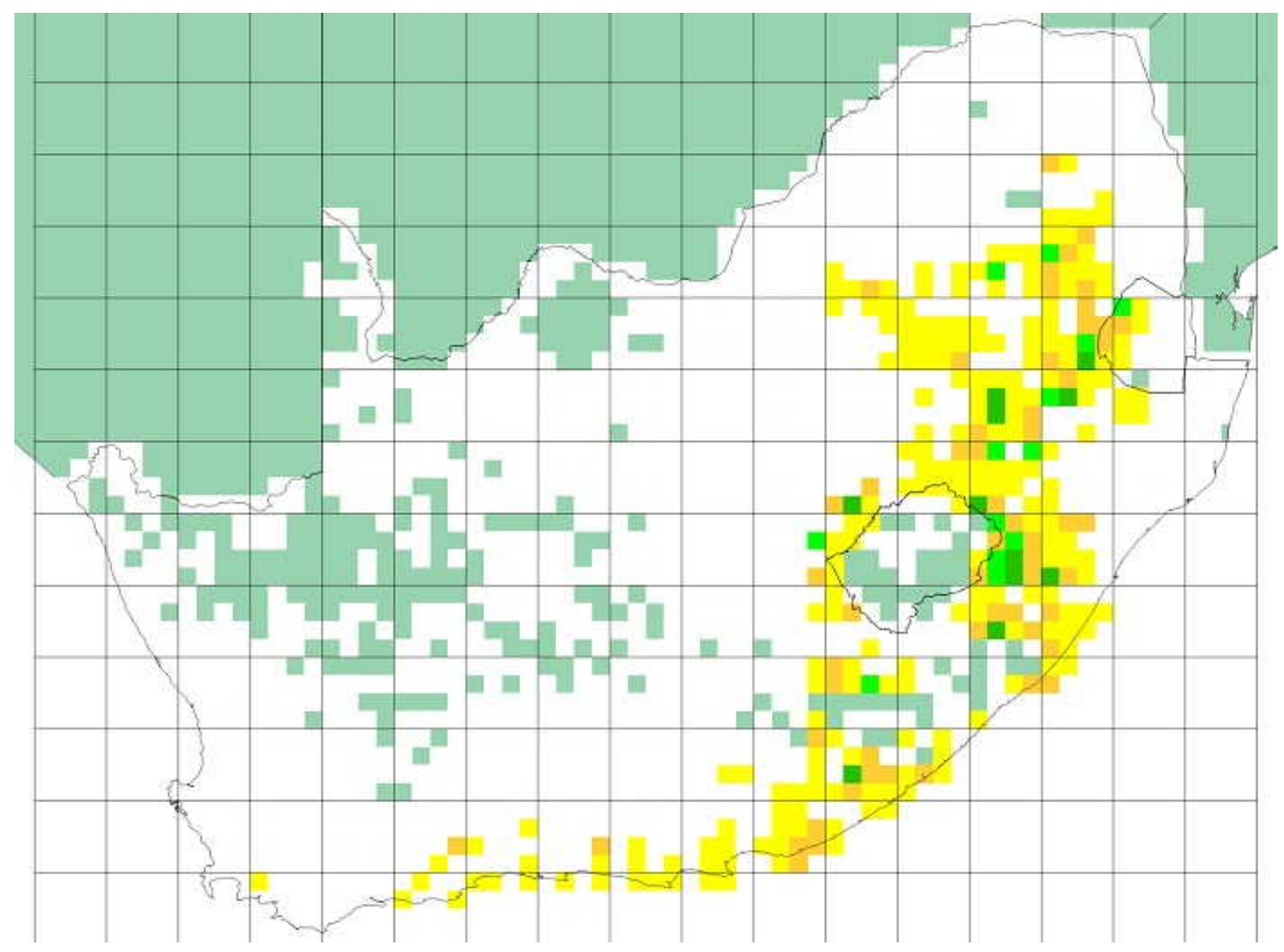

Figure 18: SABAP1 distribution map for the red-winged francolin. Note that quarter degree grid cells shaded turquoise had no SABAP1 data or fewer than four cards submitted (Mozambique, Botswana, Namibia, much of the Northern Cape Province and former Transkei). The colours represent reporting rates, and the cutpoints for the different colours are the same as used for SABAP2, see Figure 19. 


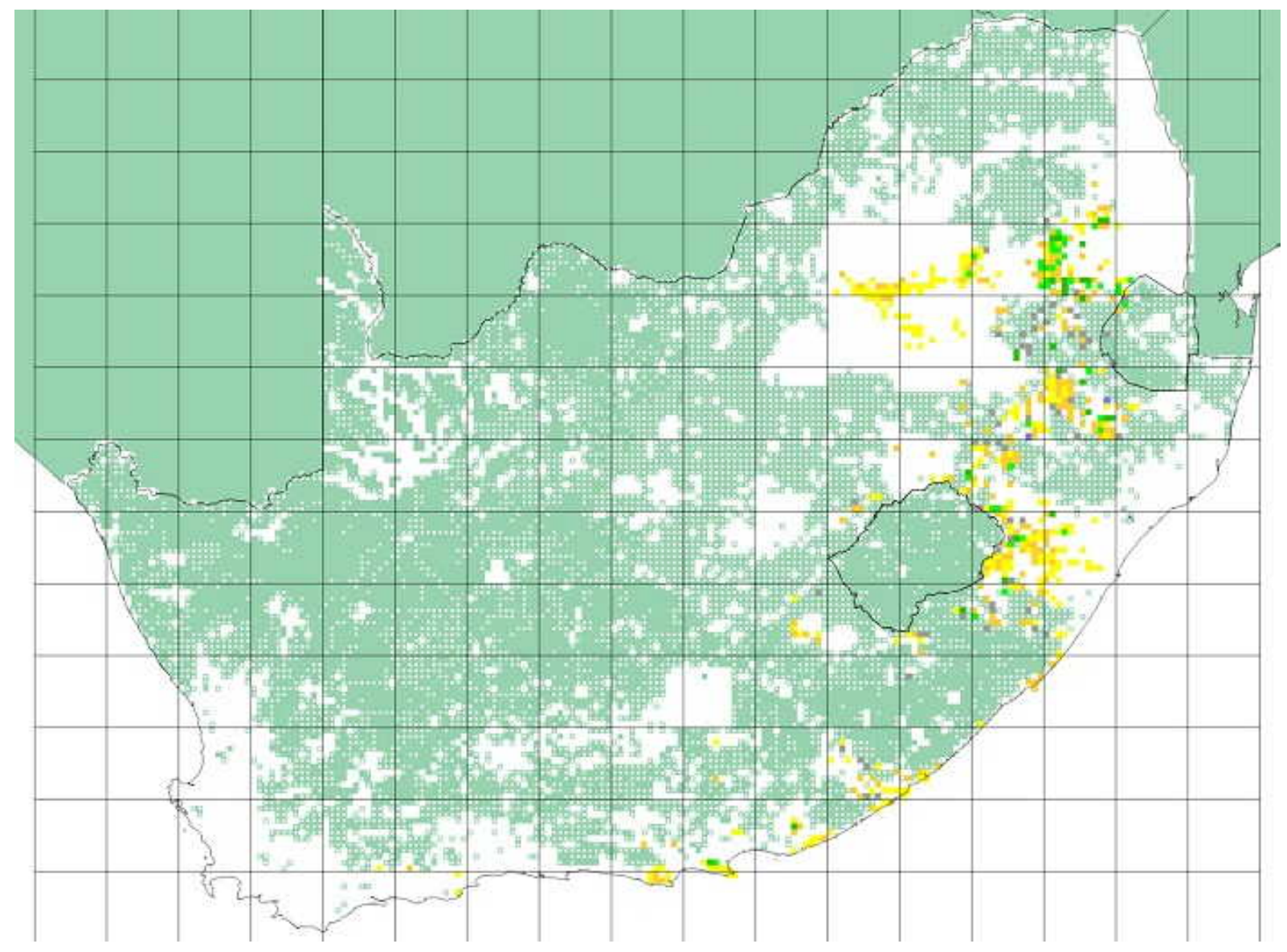

Figure 19: SABAP2 distribution map for the red-winged francolin, downloaded 19 May 2017. The detailed interpretation of this map is provided by Underhill \& Brooks (2016a). Pentads with four or more checklists are either shaded white, species not recorded, or in colour, with shades based on reporting rate: yellow $0-10.2 \%$, orange $10.2-26.3 \%$, light green $26.3-43.3 \%$, dark green $43.3-63.2 \%$, light blue $63.2-79.2 \%$ and dark blue $79.2-100 \%$. 


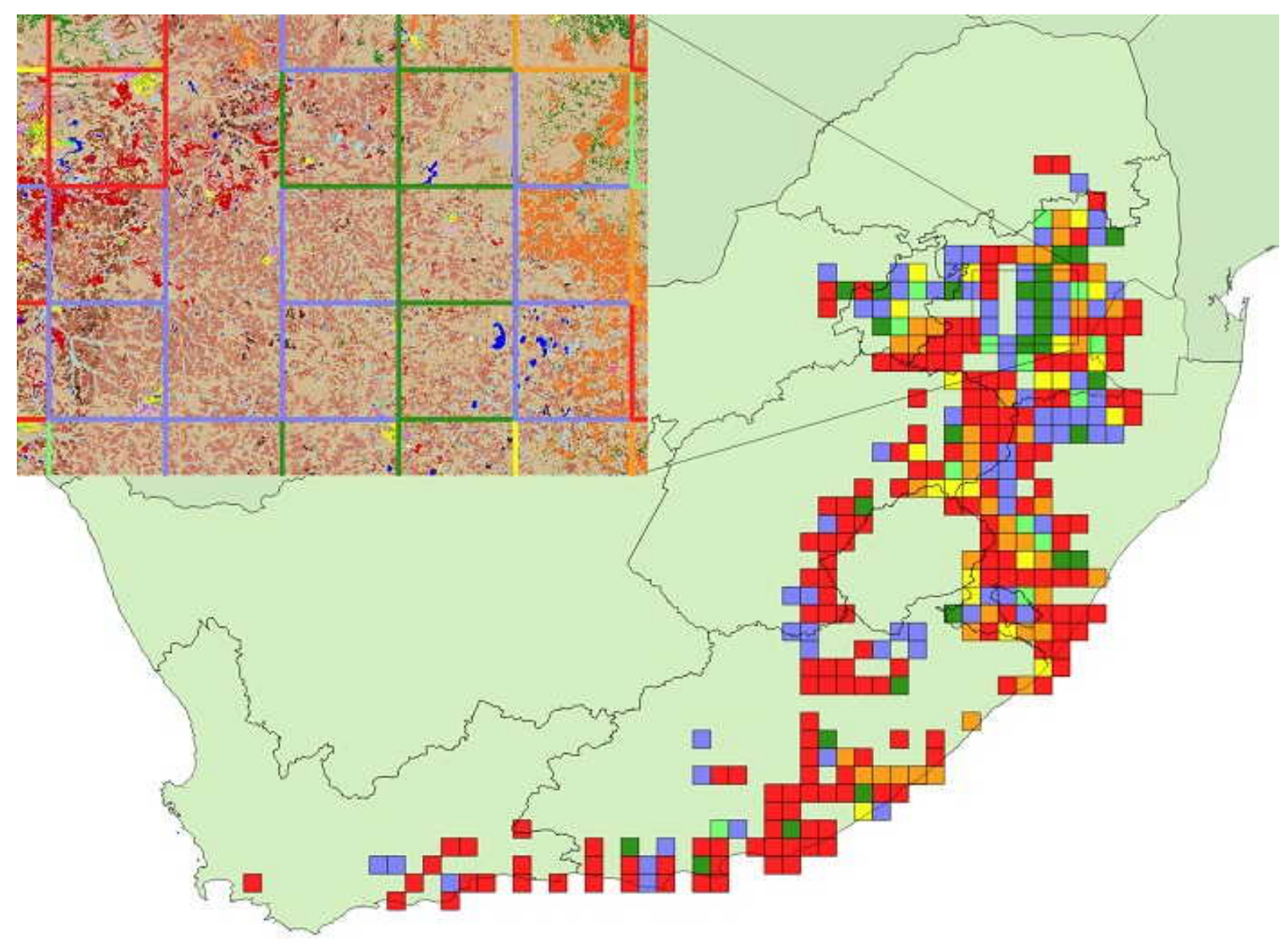

Figure 20: Range-change map between SABAP1 and SABAP2 for the red-winged francolin downloaded 19 May 2017. Red, orange and yellow represent quarter-degree grid cells with very large, large, and small relative decreases and blue, dark green and light green represent grid cells with very large, large and small relative increases. A count of the number of grid cells in each category is provided in Table 5. Only grid cells with at least four checklists in both SABAP1 and SABAP2 are shown. More detailed information on the interpretation of this range-change map is provided in Underhill \& Brooks (2016b). Inset map shows underlying land cover classes (GeoTerra Image 2015) of an area where large (green-bordered cells) to very large (blue-bordered cells) increases in red-winged francolin occurred. Coral-coloured areas are low intensity commercial agriculture and sand-coloured areas are grassland. Orange areas are depicted as plantations, red being bare mines and darker brown colours higher intensity commercial agriculture to the West of the map. 
Table 5: Range-change summary for the red-winged francolin between SABAP1 and SABAP2. Numbers (and percentages) in each colour category of Figure 20, for which there are at least four checklists per quarter degree grid cell in both SABAP1 and SABAP2. Also shown are the same summaries when the analysis is restricted to grid cells with at least 30 checklists for both SABAP1 and SABAP2.

\begin{tabular}{lrrrrr}
\hline & \multicolumn{2}{c}{$4+$ checklists } & & \multicolumn{2}{c}{$30+$ checklists } \\
\cline { 2 - 3 } \cline { 5 - 6 } Status & Count & $\%$ & & Count & $\%$ \\
\hline Red (very large decrease) & 172 & 50 & & 111 & 46 \\
Orange (large decrease) & 43 & 12 & & 36 & 15 \\
Yellow (small decrease) & 21 & 6 & & 16 & 7 \\
Light green (small increase) & 13 & 4 & & 10 & 4 \\
Dark green (large increase) & 27 & 8 & & 22 & 9 \\
Blue (very large increase) & 70 & 20 & & 44 & 18 \\
Total & 346 & 100 & & 239 & 100 \\
\hline
\end{tabular}

\section{Orange River francolin Scleroptila levaillantoides}

Found predominantly across central South Africa, Botswana and Namibia, the Orange River francolin Scleroptila levaillantoides (Figure 21) prefers grassland habitats in certain parts of its range or the presence of woody plants and cultivated fields in other areas (Little and Crowe 2011). Although this is the only species discussed here that showed large to very large increases across $\sim 50 \%$ of its distribution (Table 6 ), there were few, clustered large to very large decreases across its South African range. It was not clear why these decreases were centred around the Eastern Kalahari Bushveld Bioregion (Mucina and Rutherford 2006) as low shrubland, grassland, and the presence of woody plants seemed to be associated with these drastic changes. Towards the East of the country, commercial agriculture was dominant across grid cells that showed very large decreases as well as very large increases. One possible explanation for this unique pattern across South Africa could be that livestock grazing (not evident from the remote sensing products used here) determined the presence of this species in an area where high intensity grazing could have resulted in modifying grassland structure to such a degree rendering certain areas unfavourable for Orange River francolin. Contrary to the above pattern, this species' north-eastern distribution across the Mpumalanga, Free State, Gauteng and North-West Provinces seemed to be a large contiguous area of large to very large increases (Figure 24). This area was characterised by low to medium intensity commercial agriculture, a multitude of wetlands and grassland habitat, all in approximately equal proportions across the landscape. Another area near the boundaries of the Free State and Northern Cape Provinces showed very large increases in distribution of this species. Here, low shrubland dominated but was interspersed with the Orange River francolin's favoured habitat across its range: grassland.

\section{Acknowledgements}

This paper is part of a series, which celebrates the contributions of thousands of citizen scientists to the databases of the first and second bird atlas projects in Southern Africa (SABAP1 and SABAP2). From 2007 to March 2017, SABAP2 (Underhill 2016) was a partnership project of SANBI (South African National Biodiversity Institute), BirdLife South Africa and the Animal Demography Unit in the Department of Biological Science at the University of Cape Town. 


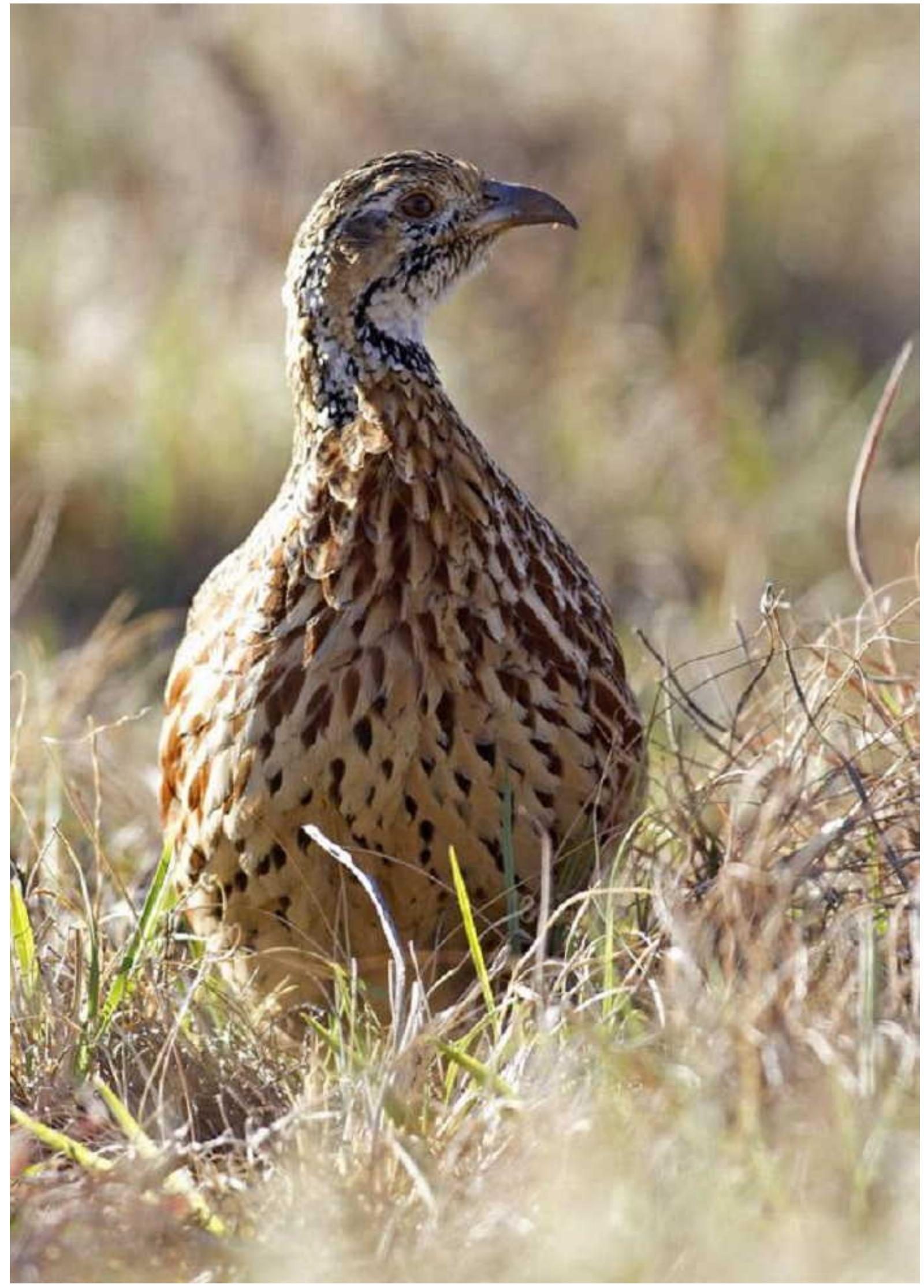

Figure 21: Orange River francolin, North-West Province. Photographer (C) SW Evans. Record 652 in the BirdPix section of the ADU Virtual Museum. Full details available at http://vmus. adu.org.za/?vm=BirdPix-652 


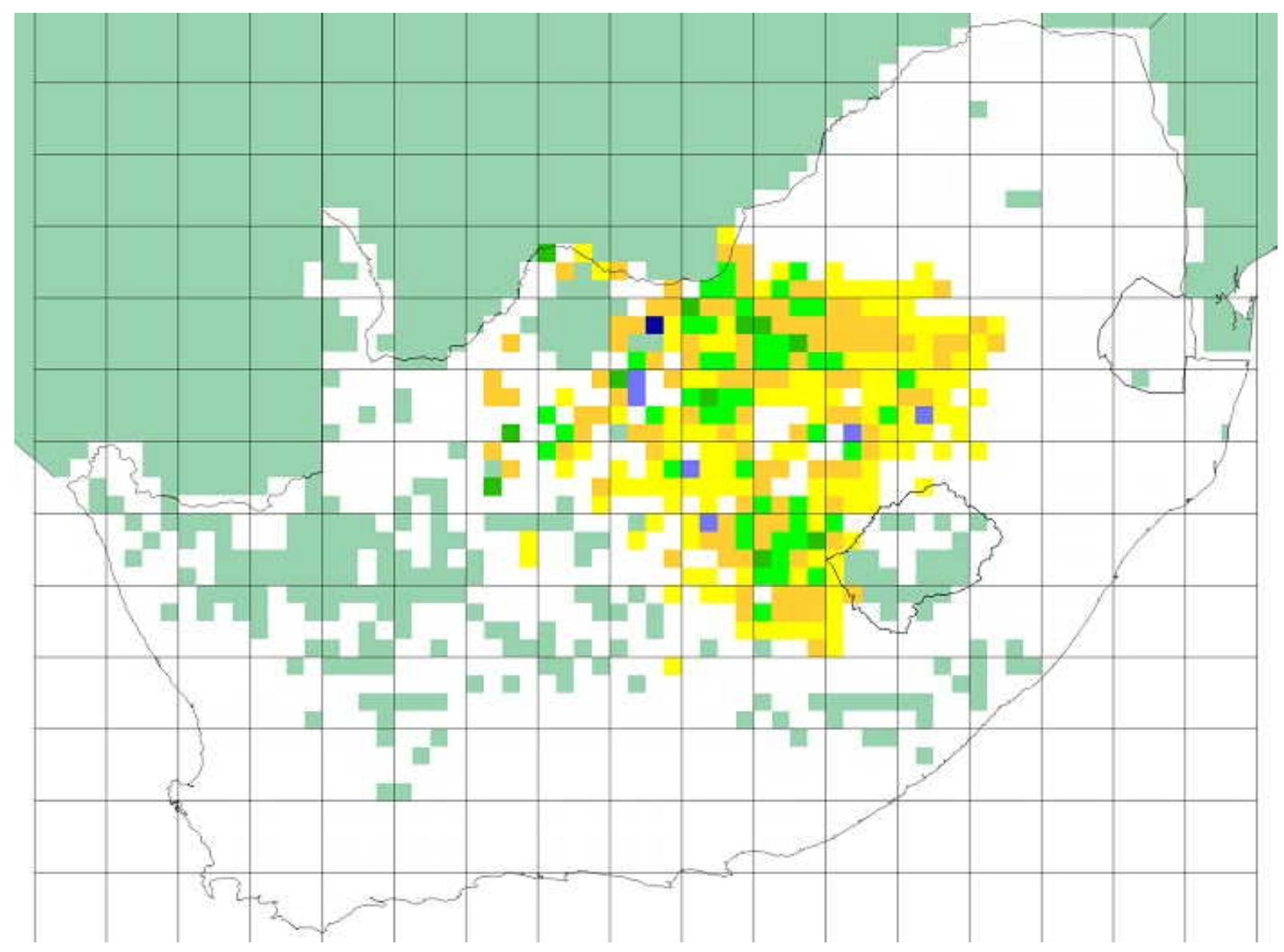

Figure 22: SABAP1 distribution map for the Orange River francolin. Note that quarter degree grid cells shaded turquoise had no SABAP1 data or fewer than four cards submitted (Mozambique, Botswana, Namibia, much of the Northern Cape Province and former Transkei). The colours represent reporting rates, and the cutpoints for the different colours are the same as used for SABAP2, see Figure 23. 


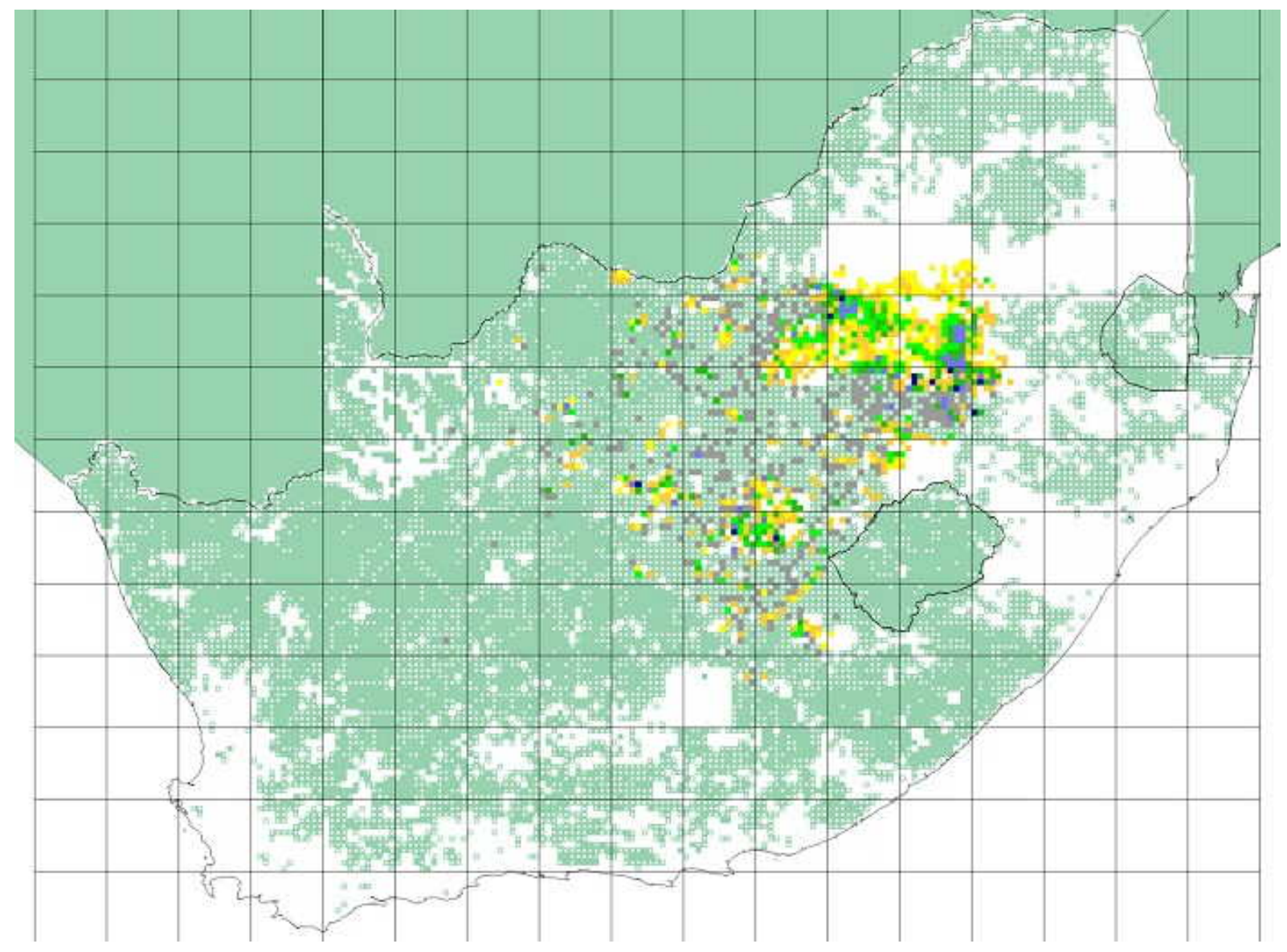

Figure 23: SABAP2 distribution map for the Orange River francolin, downloaded 19 May 2017. The detailed interpretation of this map is provided by Underhill \& Brooks (2016a). Pentads with four or more checklists are either shaded white, species not recorded, or in colour, with shades based on reporting rate: yellow $0-10.2 \%$, orange $10.2-26.3 \%$, light green $26.3-43.3 \%$, dark green $43.3-63.2 \%$, light blue $63.2-79.2 \%$ and dark blue $79.2-100 \%$. 


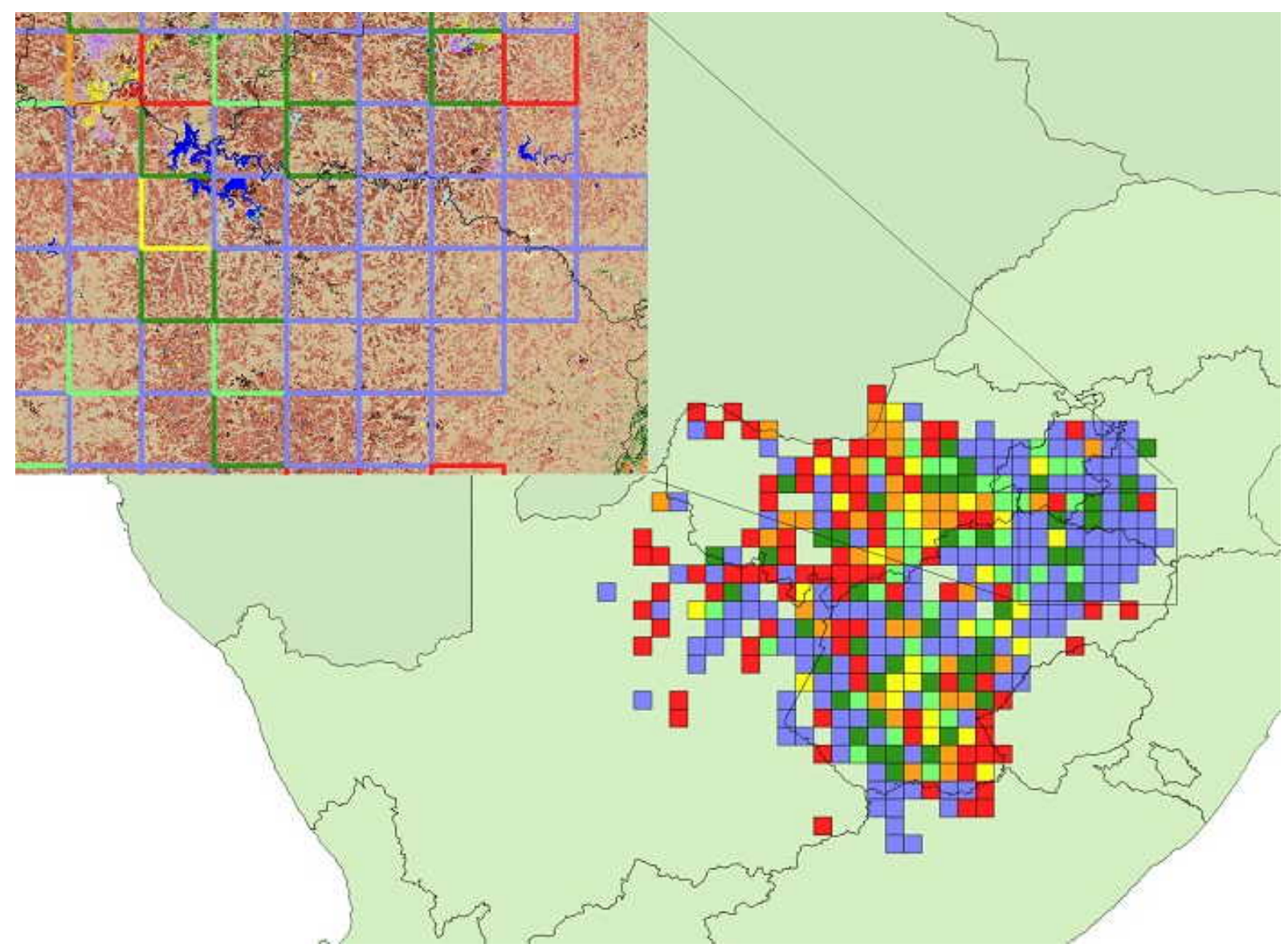

Figure 24: Range-change map between SABAP1 and SABAP2 for the Orange River francolin downloaded 19 May 2017. Red, orange and yellow represent quarter-degree grid cells with very large, large, and small relative decreases and blue, dark green and light green represent grid cells with very large, large and small relative increases. A count of the number of grid cells in each category is provided in Table 6. Only grid cells with at least four checklists in both SABAP1 and SABAP2 are shown. More detailed information on the interpretation of this range-change map is provided in Underhill \& Brooks (2016b). Inset map shows underlying land cover classes (GeoTerra Image 2015) of an area where very large (blue-bordered cells) increases in Orange River Francolin occurred. Coral and brown-coloured areas depict low to high intensity cultivated commercial fields, respectively. Sand-coloured areas are grassland. 
Table 6: Range-change summary for the Orange River francolin between SABAP1 and SABAP2. Numbers (and percentages) in each colour category of Figure 24, for which there are at least four checklists per quarter degree grid cell in both SABAP1 and SABAP2. Also shown are the same summaries when the analysis is restricted to grid cells with at least 30 checklists for both SABAP1 and SABAP2.

\begin{tabular}{lrrrrr}
\hline & \multicolumn{2}{c}{$4+$ checklists } & & \multicolumn{2}{c}{ 30+ checklists } \\
\cline { 2 - 3 } \cline { 5 - 6 } Status & Count & $\%$ & & Count & $\%$ \\
\hline Red (very large decrease) & 87 & 23 & & 17 & 13 \\
Orange (large decrease) & 36 & 9 & & 13 & 10 \\
Yellow (small decrease) & 28 & 7 & & 10 & 8 \\
Light green (small increase) & 36 & 9 & & 14 & 11 \\
Dark green (large increase) & 47 & 12 & & 14 & 11 \\
Blue (very large increase) & 149 & 39 & & 58 & 46 \\
Total & 383 & 100 & & 126 & 100 \\
\hline
\end{tabular}

\section{References}

Crowe TM, Harley EH, Jakutowicz MB, Komen J, Crowe AA 1992. Phylogenetic, Taxonomic and Biogeographical Implications of Genetic, Morphological, and Behavioral Variation in Francolins (Phasianidae: Francolinus). The Auk 109.1:24-42

GeoTerra Image 2015. 2013-2014 South African National Land-cover dataset. Pretoria

Hockey PAR, Dean WRJ, Ryan PG (eds) 2005. Roberts Birds of Southern Africa, VIIth edition. The Trustees of the John Voelcker Bird Book Fund, Cape Town

Jansen R, Little RM, Crowe TM 1999. Implications of grazing and burning grasslands on the sustainable use of francolins (Francolinus spp.) and on overall bird conservation in the highlands of Mpumalanga Province, South Africa. Biodiversity and Conservation 8:587-602

Jansen R, Little RM, Crowe TM 2000. Habitat utilization and home range of the redwing francolin, Francolinus levaillantii, in highland grasslands, Mpumalanga Province, South Africa. African Journal of Ecology 38:329-338

Jansen R, Robinson ER, Little RM, Crowe TM 2001. Habitat constraints limit the distribution and population density of redwing francolin, Francolinus levaillantii, in the highland grasslands, Mpumalanga Province, South Africa. African Journal of Ecology 39:146-155

Little RM 2005a. Coqui Francolin Peliperdix coqui. In: Hockey PAR, Dean WRJ, Ryan PG (eds) 2005. Roberts Birds of Southern Africa, VIIth edition. pp. 79-80. The Trustees of the John Voelcker Bird Book Fund, Cape Town

Little RM 2005b. Crested Francolin Dendroperdix sephaena. In: Hockey PAR, Dean WRJ, Ryan PG (eds) 2005. Roberts Birds of Southern Africa, VIIth edition. pp. 63-64. The Trustees of the John Voelcker Bird Book Fund, Cape Town

Little RM 2005c. Shelley's Francolin Scleroptila shelleyi. In: Hockey PAR, Dean WRJ, Ryan PG (eds) 2005. Roberts Birds of Southern Africa, VIIth edition. pp. 66-67. The Trustees of the John Voelcker Bird Book Fund, Cape Town

Little RM 2005d. Red-winged Francolin Scleroptila levaillantii. In: Hockey PAR, Dean WRJ, 
Ryan PG (eds) 2005. Roberts Birds of Southern Africa, VIIth edition. pp. 65-66. The Trustees of the John Voelcker Bird Book Fund, Cape Town

Little RM, Crowe TM 2011. Gamebirds of Southern Africa. Struik Nature, Cape Town

Mucina L, Rutherford MC 2006. The vegetation of South Africa, Lesotho and Swaziland. South African National Biodiversity Institute.

Ratcliffe CS 2005. Chukar Partridge Alectoris chukar. In: Hockey PAR, Dean WRJ, Ryan PG (eds) 2005. Roberts Birds of Southern Africa, VIIth edition. pp. 61-62. The Trustees of the John Voelcker Bird Book Fund, Cape Town

Underhill LG 2016. The fundamentals of the SABAP2 protocol. Biodiversity Observations 7.42:1-12. Available online at http:// bo.adu.org.za / content.php?id=235

Underhill LG, Brooks M 2016a. Pentad-scale distribution maps for bird atlas data. Biodiversity Observations 7.52:1-8. Available online at http://bo.adu.org.za/content.php?id=245

Underhill LG, Brooks M 2016b. Displaying changes in bird distributions between SABAP1 and SABAP2. Biodiversity Observations 7.62:1-13. Available online at http://bo.adu.org. za/content.php?id=255

Viljoen PJ 2005. AGRED's Gamebirds of South Africa: field identification and management. African Gamebird Research Education and Development Trust, Johannesburg 